\title{
Lapita and the temporal geography of prehistory
}

\author{
JOHN EDWARD TERRELL \& ROBERT L. WELSCH*
}

Ambrose (this issue, above) and Sand (this issue, above) reported on Lapita in the specific, without being parochial in their concerns. This paper looks at the largest Lapita picture, but is itself in turn based on new reports in the specific, here from the coast of Papua New Guinea which is key for the relations in space, in time and in cultural affinity of whatever human it is that Lapita is.

Lapita is an ornate style of pottery found at archaeological sites in Oceania (Spriggs 1990). Sherds in this style have been unearthed on islands located in a wide arc of the southwestern Pacific, from Aitape on the Sepik coast of New Guinea and stretching all the way eastward to Fiji, Tonga, and Samoa (Green 1994). In the 1960s, when the style was given its name, no one appears to have anticipated that Lapita would be 'a hot source of debate' (Bellwood \& Koon 1989: 613) in the decades ahead. Lapita pottery was quickly associated with the settlement of the Pacific by Malayo-Polynesian (i.e. Austronesian) speakers (Suggs 1960); it was judged to have been created by migrants from Southeast Asia; and it was soon identified as the hallmark - the index fossil - of 'the ancestral cultural complex from which Polynesian culture was derived' (Green 1973: 332; 1974). As Matthew Spriggs (1984: 203) once summarized the argument, this initial interpretation of Lapita pottery required 'a fairly direct transfer of culture, genes and language from Island Southeast Asia'.

Although this reading of Lapita still has its advocates, nowadays perhaps more numerous outside Pacific archaeological circles than inside, objections have been raised against this straightforward assessment of Lapita's place in prehistory. Lapita as an empirical phenomenon is poorly known and reported in the literature; for the most part, its associations (i.e. Lapita as a 'cultural complex') are also poorly known; interpretations of Lapita have outstripped the actual data available; and 'far from Lapita being a basically intrusive Southeast Asian cultural complex, its form and much of its content may have developed in the northwest Melanesian area' (Spriggs 1984: 222-3).

Scholars working in other parts of the world may wonder what difference it makes if the Lapita style was imported from Asia or developed locally in Melanesia, or if it is the hallmark of a true cultural complex. Getting Lapita's origins and place in prehistory right, however, are not just parochial concerns. As Sherratt (1993: 126) has said, the spatial scale of phenomena such as the Bell Beaker culture or the Lapita complex renders inadequate any methodology based solely on case-studies that privilege local understanding at the expense of wider settings. One of the oldest debates in science is about whether events and processes that we see going on around us are sufficient to explain the character of large-scale phenomena. Some would say that the colonization of a region as big as Oceania requires abnormal explanations: solutions that are qualitatively different from those used by historians and other social scientists to account for patterns of diversity among contemporary or historic people. But was the Lapita phenomenon as remarkable as some say? Here we construct three qualitative models to illustrate how competing interpretations of Lapita differ. We have some new data to present. But we find that the major difference among

* Field Museum of Natural History, Roosevelt Road \& Lake Shore Drive, Chicago IL 60605, USA.

E-mail: terrell@fmppr.fmnh.org

Received 17 June 1996, accepted 13 November 1996, revised 21 March 1997.

ANTIQUITY 71 (1997): 548-72 
these interpretations is the discordant ways in which archaeologists and others configure the temporal geography of the past.

\section{Temporal geography}

The expression temporal geography is unorthodox. Geography is normally said to be about the study of spatial rather than temporal phenomena. The expression also sounds like a play on the more conventional phrase locational geography which is - or was back when the 'new geography' was new and positivism was still fashionable - about the geography of things in one, two or three dimensions (Haggett 1966). In this essay, we want the resemblance to be more than a play on words. Experience teaches us that our world has four - not just one, two or three - dimensions. Measuring and modelling the patterning of social activities, the movements of people, and the diffusion of ideas, traits and practices in space and time have long been of interest to sociologists as well as geographers (Gell 1992). Archaeologists know geography is not static. The natural world and the constructed landscapes that people create are ever changing. Therefore - in words that may pass muster in our post-modern world - let us say temporal geography is about the ways in which we conceptualize and study the history and inter-relationships of things in the four dimensions of space-time.

These kinds of understandings are sometimes labelled paradigms or worldviews. An obvious paradigm of temporal geography is the Biblical story of the Garden of Eden and its modern counterpart, cosmological theories of a primordial Big Bang (Hawking 1988). There are key similarities between these views of space, time and history. The beginning of things in both cases is said to have started at a single point in time and space, although the dimensions and original conditions critical to each understanding are markedly dissimilar. History is accountable as the movement of created things away from that place and time of origin. History, like Janus, has two faces. Movement through time and space is evidenced by change or transformation away from the original state or conditions of existence. Yet history is marked by the preservation of the substance of creation. All that exists is descended from what once existed. Movement through time and space is unbroken. The essence, force or energy of crea- tion is conserved as well as transformed.

While subtleties are lost in so doing, these several conceptual elements can be reduced to four:

Origins: Time is thought to run back in an unbroken line from the present to the day and place of creation.

Movement: History tells us of the movement of things through space and time away from that centre of creation.

Descent: Descent is the preservation of our continuities with the past.

Change: Change is the transformation of the original force or substance of life through movement away from the centre of origin, through the endless cycle of births and deaths, and through the adaptation of living things to their local circumstances.

Reducing the Garden of Eden and the Big Bang theory of creation down to these four constituent parameters reveals how other conceptions of temporal geography may be isomorphic with such intellectual constructions. Diffusion and migration are commonly said to be different because the 'actual mechanics of movement' differ (Adams et al. 1978: 486). Certainly a difference in mechanics can be important. And scholars who think similar assemblages of artefacts and other kinds of materials 'may be said to comprise a culturally homogeneous population or people' (Rouse 1986: 3) may favour migrational theories over diffusionist explanations. Structurally, however, the parameters of disagreement among these four conceptions may be quite narrow (Adams et al. 1978).

\section{The riddle of Lapita}

In 1960 Robert C. Suggs (1960: 70) reported in The island civilizations of Polynesia 'some unusual pottery' with stamped and incised decorations which had been recently excavated in southern Melanesia at a locality in New Caledonia called Lapita (site 13). He noted that this distinctive type of pottery was also showing up at archaeological sites in the Fiji Islands. By then, in fact, Lapita pottery had been discovered also on small Watom Island in the Bismarck Archipelago and in the Tongan Islands east of Fiji (Gifford \& Shutler 1956).

Fiji, New Caledonia and the Bismarcks are all in the cultural territory conventionally labelled 'Melanesia' (Black Islands) on maps of the Pacific. The Fiji Islands are usually thought 
to be the most easterly outpost of dark-skinned Melanesians in the Pacific. Most maps make the western side of the great triangle connecting Hawaii, Easter Island and New Zealand the famous 'Polynesian triangle' - skirt around Fiji so that the lighter-skinned Tongans and Samoans are inside the triangle but Fijians are not. Thus by 1960 Lapita pottery had turned up not only in Melanesia but also in Polynesia.

Jack Golson proposed that the discovery of Lapita sherds on both sides of the dividing line between Polynesia and Melanesia indicated that this conventional boundary needed to be rethought. Evidently some kind of continuity or 'early community of culture' ancestral to the historic cultures of Polynesia had reached Fiji and Tonga before the 'Melanesian cultures' of Melanesia had got as far as Fiji (Golson 1961: 176). As Roger Green rephrased this observation in 1966: 'it is only with the intrusion of . . . later Melanesian cultural traditions into island groups of eastern Melanesia such as New Caledonia, Fiji, and Lau, probably around the 1st century BC, that one is able to draw a distinct boundary between Polynesia and Melanesia' (1968: 106).

This way of looking at Lapita's geographic distribution in the Pacific implies that this pottery has more to tell us about Polynesians than about Melanesians (Kirch \& Weisler 1994; Smith 1995). Is this true? Consider the following. With the exception of Tonga (and Samoa, where Lapita pottery has also turned up), Lapita is not really Polynesian pottery. Instead, Lapita is Melanesian pottery par excellence, or as the archaeologist Jean Kennedy once wrote, Lapita has 'a Melanesian distribution with a Polynesian extension' (1982: 24). Yet some link Lapita not only with ancestral Polynesians in Tonga and Samoa but also with early southeast Asia pottery-making and the inferred Asian homeland of not only the Polynesians but of all Austronesian-speaking peoples (Bellwood 1975; 1978a; 1978b; Brace \& Hinton 1981; Shutler \& Marck 1975; Solheim 1964). But Lapita pottery has never been found in Asia, the Philippines or Indonesia. And many Austronesian-speaking peoples are Melanesians. So here is the riddle of Lapita. If man was the correct answer to the Riddle of the Sphinx, is Lapita the answer to this modern counterpart: What is Asian in its origins, Melanesian in its distribution and Polynesian in its maturity?
As we have said, two different ways of answering this contemporary riddle have long been debated by Pacific experts. The first sets the homeland of Lapita in Asia; the second finds its roots in Melanesia. Nowadays, as we shall describe, there is willingness to think both of these solutions may be partly right. But we do not think this new ecumenical spirit goes far enough. Therefore, we introduce a third, one we call the voyaging corridor model. But let us start with Asia where the first solution begins.

\section{Asians in the Pacific (a culture historical model)}

Since the 1970 s Peter Bellwood has been perhaps the most vocal proponent of a direct Asian or island southeast Asian homeland for Lapita and the Polynesians. In Man's conquest of the Pacific (1978), the first textbook on Pacific archaeology, Bellwood argued that Lapita pottery shows us that a number of highly mobile Austronesian-speaking groups of sea-borne colonists and explorers had expanded rapidly through Melanesia and on into Polynesia about 1300 BC (1978a: 244). Furthermore, 'we may accept that an immediate origin for Lapita lies somewhere in the Philippines or north-eastern Indonesia, between 2000 and $1300 \mathrm{BC}$, and the general locality should be pinned down more thoroughly in the near future' (Bellwood 1978a: 247; also 1993: 158). He foresaw, nonetheless, that the Austronesian expansion into Melanesia 'was by no means a simple matter, and the initial migration which introduced the languages ancestral to the present Oceanic subgroup [of Austronesian languages] may well have taken place some 5000 years ago' (Bellwood 1978a: 244; 1978a: 255; but see Bellwood 1989b: 25).

Bellwood has not been alone in favouring this solution. The claim that Asian migrants now and then swept over the Pacific Islands is not new. Back when even physical anthropologists thought human beings had once come in the primal colours of white, black, brown, red and yellow, there seemed to be no other way to explain why Polynesians may look different in their appearance from Melanesians. But as Bellwood (1997a: 22) noted recently, 'as far as Lapita is concerned, my own view, and that of many other archaeologists including Patrick Kirch of the University of California at Berkeley, is that the Lapita culture represents the Austronesian-speaking Neolithic populations 
that colonized Oceania (Melanesia, Micronesia, and Polynesia) beginning $c a .1500$ BC'. And Matthew Spriggs has similarly written that if one had been 'set down in a settlement on Taiwan, Timor, Manus and perhaps even Tonga in $3000 \mathrm{BP}$ one would find oneself in the same cultural milieu' (1989: 608; also Gosden \& Pavlides 1994). His conclusion: while the causes for the intrusion from southeast Asia remain obscure, the Lapita cultural complex must have entered Melanesia as a 'physical migration' of people from southeast Asian whose success 'may have been due to the demographic advantages imparted by an integrated animal husbandry and agricultural economy in an area previously inhabited by low-density hunter-gatherer or lowintensity horticultural groups' (Spriggs 1996b: 342).

In outline, therefore, here are general elements of this kind of solution to the riddle of Lapita:

\section{STAGE I}

Temporal episode: The first Melanesians got to the Pacific from southeast Asia long before the ancestors of the Polynesians. (In this solution to the riddle, people in Australia and the highlands of Papua New Guinea are seen as relict human populations whose ancestors were not touched by the Lapita expansion; they are the purest living descendants of people who once roamed widely in island southeast Asia - so Australians and New Guineans comprise temporal as well as geographic populations; see Chen et al. 1992; Nei \& Takezaki 1996.)

Geographic result: Once in the Pacific, these darkskinned pioneers had little or no contact with people back in southeast Asia (evidently because they were hunter-gatherers).

\section{STAGE II}

Temporal episode: Sometime after 4000 years ago, a migration (Bellwood 1978a: 255; 1989b; Kirch \& Weisler 1994; Spriggs 1996b: 339) of lighterskinned pottery-using horticultural people from Asia broke through the remoteness of Melanesia.

Geographic result: Directly through intermarriage, or indirectly through cultural diffusion, these foreign colonists established Neolithic arts as well as the Austronesian languages in the Pacific (Bellwood 1992: 50).

\section{STAGE III}

Temporal episode: Sooner or later some of these migrants got as far as Polynesia without intermarrying significantly with Melanesians (Bellwood 1978a: 255).
Geographic result: Their descendants, the Polynesians, still preserve much of the cultural and biological endowment of the ancient Lapita migrants; 'Here, in the isolation provided by $900 \mathrm{~km}$ of water between the New Hebrides [Vanuatu] and Fiji, they became the founding populations' of Polynesia (Green 1974: 254; also Green 1973: 332).

Readers will note that this answer to the riddle has a familiar ring. While nowadays Bellwood, Spriggs and others are somewhat equivocal on the status of pre-Lapita economic and cultural achievements in the Pacific (e.g. Bellwood 1989a: 22, 39; 1991; 1993; Loy et al. 1992; Spriggs 1989: 609; 1993a; b; 1996b: 342), this is a well-known stadial model (Groube 1967) of cultural evolution customized for Oceania. The axes of space and time are marked into two main blocks that elsewhere in the world would be labelled Palaeolithic and Neolithic. This solution is also isomorphic with the Garden of Eden and the Big Bang. Instead of an apple or an explosion of epic proportions, a major event - the migration of a culturally more evolved people - took the Pacific out of the hunter-gatherer stage of development and into more complicated times. Importantly, the Neolithic revolution is believed to have taken place elsewhere, specifically in Asia. When Neolithic times eventually arrived in the Pacific, racial admixture occurred in Melanesia but not in Polynesia, Australia and parts of New Guinea where people were isolated enough from southeast Asia to remain true to their original endowment.

The axes of space and time (TABLE 1) in this understanding of temporal geography in the Pacific are determinate. The geographic divide between southeast Asia and Melanesia that we now recognize was evidently in place at the beginning of human movements out of Asia (Spriggs 1996b: 327); similarly, the transition from the Palaeolithic to the Neolithic starting around 4000 вP was an episode we can mark off in time - so clearly that we can actually determine who was responsible (Asian colonists) and what they did to achieve such a momentous undertaking (Terrell 1990; 1996).

\section{Lapita's Melanesian homeland (an evolutionary model)}

Other interpretations of Lapita pottery are possible. Since the late 1970s, Jim Allen and Peter White have championed a Melanesian home- 
model

space

time

Asians in the Pacific determinate Melanesian homeland determinate voyaging corridor relative determinate relative relative
TABLE 1. The temporal and spatial parameters of three Lapita models.

land for Lapita and - by extension of their argument (White 1979: 372-4) - for the Polynesians. In 1978 White and colleagues reported stone tools and waste chips - some of obsidian - at Balof, a small limestone rock-shelter on the east coast of New Ireland, where human settlement could be dated back as far as $c$. 6000-7000 years ago. Analysis of 45 pieces of obsidian revealed that obsidian in the lower levels of the site came from the Talasea area on the north coast of New Britain in the Bismarck Archipelago. Some of the obsidian from the middle layers was from Lou in the Admiralty Islands, also located in the Bismarcks. 'It is probably significant that, whereas $600 \mathrm{~km}$ of coastal travel are required to move obsidian from Talasea to Balof, a direct voyage of more than $150 \mathrm{~km}$ as well as coastal travel is required to transport Lou Island obsidian there' (White et al. 1978: 878). Here at one and the same time, they said, was evidence both for pre-Lapita settlement in the southwestern Pacific and also for the claim 'that the wide-ranging cultural phenomenon of Lapita pottery manufacture and the long-distance movement of obsidian grew out of already existing conditions'. In short, the Balof evidence supported 'a gradualist model of island Melanesian settlement rather than an abrupt settlement by pottery-making horticulturalists'.

Two years later White \& Allen published an overview of archaeological research in Melanesia. In light of Green's (1979: 45) recently published hypothesis that Lapita as a cultural complex had been developed in the Bismarck Archipelago apparently by people from island southeast Asia, they wrote (White \& Allen 1980: 733) that since the Bismarcks had been settled long before the advent of Lapita pottery

and since there is no archaeological evidence of southeast Asian presence in the area so early, we question the need to elaborate the simpler hypothesis of local cultural development. We agree that some contact between the Bismarcks and islands to the west is likely around 4000 or more years ago and that such contact may have resulted in the acquisition of certain items and technological knowledge, but we think that most of the technical knowledge and economic aspects of the [Lapita] complex could have developed within a local context.

Since 1980 White, Allen and others have reiterated and further documented the reasons they favour this home-grown solution. The riddle itself was the central rationale for a major programme of archaeological investigations in the Bismarck Archipelago during 1985, the Lapita Homeland Project (Allen \& Gosden 1991). Perhaps in response to some of the project's collaborators who argued emphatically after the project was over that a homeland for Lapita in the Bismarcks is unlikely (Allen 1991; Kirch 1987; 1988c; Kirch et al. 1991; Spriggs 1993a), Allen \& White wrote not long after the project's field work was finished (1989: 142):

Nowhere did the [Lapita Homeland] project encounter any antecedents of the fully developed Lapita ceramics. This must reaffirm that the technology of pot making was introduced, presumably from the west. Whether this was from the New Guinea mainland or further west remains to be determined either is possible - but 4000 or more years ago there is some evidence of expansion and colonization in the Bismarck Archipelago. This probably had its background in the networks which had moved obsidian and other stone (and what else?) round this area for many millennia. ... We can envision that Lapita pottery was the result rather than the cause of expanding voyaging and exchange (or trading) networks.

Like the first solution favouring an Asian homeland for Lapita, this second model takes it more or less for granted that people in Melanesia were isolated from people in southeast Asia until local developments within the Bismarck Archipelago reached the point where people there were able to acquire technologies, such as the art of pottery-making, from outside sources (Allen 1984: 194). And nearly everyone agrees nowadays - regardless of which solution they favour - that Lapita as a distinctive pottery style was developed by people in the Bismarck Archipelago (Allen 1984: 194; Bellwood 1992; Green 1994: 36; Irwin 1992: 36; Kirch 1997: 52, 142-3; Spriggs 1984: 206; 1989: 607). At issue is the question Who were these people? 
STARTING CONDITIONS

Temporal: One outcome of recent archaeological research is that we now know people have been living in the Bismarcks and elsewhere in the southwestern Pacific for more than 30,000 years (Allen \& Holdaway 1995; Pavlides \& Gosden 1994).

Geographic: 'From well before the Pleistocene ended we have clear evidence of deliberate sea movements which transferred obsidian from New Britain to New Ireland and probably transferred animals as well' (Allen 1991: 5; e.g. Flannery \& White 1991).

\section{EVOLVING CIRCUMSTANCES}

Temporal: Therefore, people in the southwest $\mathrm{Pa}$ cific had time before the advent of Lapita some 3500 years ago to master 'the problems of surviving in the island world of the Bismarck Archipelago' (Allen 1991: 7).

Geographic: Their mastery was skilful enough that these Melanesians must have come increasingly in contact with other groups farther to the west.

\section{RESULT}

Temporal: Consequently there is no need to argue that Lapita shows us the rapid spread of Austronesian-speaking colonists out of southeast Asia 'streaming eastwards and bearing their superior technology, social organization and subsistence modes towards a Polynesia-to-be' (1991: 1).

Geographic: 'Such contacts would have facilitated the flow of materials, technologies and people in both directions' (1991: 7; also Allen 1996: 26).

In short, "the human history of the region may for the most part be economically explained in terms of local development. This is not to deny westerly contacts both before and after the Lapita florescence' (Allen 1984: 192, emphasis added).

We think the Achilles heel of this solution is figuring out what 'for the most part' means (White 1979: 374). As the authors of one report on the Lapita Homeland Project have written: 'The Bismarck archipelago was not hermetically sealed from all outside influence at any period; however, neither was the course of its prehistory totally altered by immigrants from the outside. Future models will therefore have to balance external and local factors in a convincing manner' (Gosden et al. 1989: 577). Note, nevertheless, that the axis of time in this alternative understanding of temporal geography in the
Pacific is differently configured than time in the Asian origins model (TABLE 1). While Lapita is still seen as a determinate episode in prehistory (a 'florescence'), exactly when any particular cultural element identified with Lapita appeared in the Bismarcks is indeterminate: it depends on which cultural element one is talking about. Time in this understanding of temporal geography is relative rather than determinate. But as in the Asian origins model, geography remains determinate. There was a geographic divide (if nothing else, isolation by distance) between southeast Asia and Melanesia thousands of years ago, just as there is (perhaps) today. Eventually, however, some people broke out of Lapita's homeland (its own Garden of Eden) in the Bismarcks and brought back home the art of pottery-making from somewhere to the west.

\section{A compromise solution? (an 'à la carte' model)}

Lately it has been suggested that the limitations of both the Asian origins and Melanesian homeland models can be overcome if they are combined into a more sophisticated, more balanced model of Lapita and Austronesian dispersals (e.g. Green 1994: 35-6; Kirch 1997: 44-7). As Kirch \& Weisler (1994: 291) have summarized this possibility:

That some movement of people from island southeast Asia into the Bismarcks occurred in the mid second millennium $\mathrm{BC}$, and that this was responsible for the emergence of the Lapita ceramic complex, seems firmly established; the linguistic picture of Oceanic is consistent with such a view. At the same time, it is clear that the Lapita complex incorporated indigenous Melanesian cultural developments and that nonAustronesian speaking (and genetically diverse) people were also involved in the 'Lapita phenomenon'.

This compromise keeps Lapita as a determinate temporal episode and as with the Melanesian homeland model, we are still faced with the problem of figuring out how 'Melanesian' or 'Asian' Lapita was. According to Green, assessments of Lapita must now attempt to distinguish those new elements from southeast Asia that were intrusive from those that became an integral part of this complex through contacts with communities in Melanesia that were already in residence (Green 1994: 36). In Green's 
words (1994: 35), the middle road between the Asian origins and Melanesian homeland models 'stipulates that each of the cultural elements in the Lapita cultural complex should be assessed as to whether it derives from those components already present ... (integration), those which constitute new additions from outside that long-settled region (intrusions), and those which are first evident in Lapita itself (innovations)'. As Bellwood (1993:158) and Spriggs (1993b: 139-41) have observed, this is a hard job. Do we really have to sort elements of the Lapita cultural complex into three separate piles labelled Asian, Melanesian and new? Were southeast Asia and Melanesia separate and divergent enough back then to make the task worthwhile?

\section{The 'voyaging corridor' (an historical model)}

In an earlier issue of ANTIQUITY, John Terrell argued that Pacific Islanders should be thought of as a geographic set of local and island populations, more or less in touch with one another, that have followed separate but often connected historical pathways of local adaptation and culture change (Terrell 1988; also 1986). A year later, again in ANTIQUITY, he also noted (Terrell 1989) that the modern government of Indonesia would insist that New Guinea is as much a part of Island Southeast Asia as it is part of Melanesia (see Swadling 1996). Unfortunately archaeologists have only started to document the ties and interactions that may have pulled people living in this meeting ground between Asia and the Pacific into an interaction sphere (or a set of interlocking spheres) possibly from the very start of settlement in this part of the world (e.g. Tykot \& Chia 1997).

The idea that human communities are linked together into interaction spheres is an Americanist concept (Caldwell 1964). Geoff Irwin and Terrell found this concept useful in their field work in the Solomons in 1969-70 (e.g. Terrell \& Irwin 1972). In 1974 Terrell introduced a simple graph-theoretic technique to model likely interaction spheres, a technique he called proximal point analysis (Terrell 1974). Others have found this technique useful (Green 1979; Hunt 1987; 1988; Kirch 1990; 1991). We think, however, that Brian Egloff was possibly the first to see the full implications of the concept of interaction spheres for Pacific prehistory. In a 1975 report on his archaeological investigations in the Madang area of northeastern New Guinea and on Eloaue Island in the St Matthias group, Egloff asked rhetorically whether it might be appropriate to think of the peoples of Melanesia as 'members of a series of overlapping interaction spheres', the extent and importance of which had varied over time and space (Egloff 1975: 30). If that had been the case, then 'cultural differentiation in island Melanesia should not be considered simply in terms of migration, settlement and subsequent isolation with limited interaction, but as resulting in part from a pattern of interaction which gave seaborne communities alternative strategies from which to select' (1975: 31).

Several years later Jean Kennedy, after weighing arguments for and against the origins of the Lapita style in southeast Asia, added a telling point. We know too little, she said, about Lapita's Melanesian context to resolve the question of Lapita's origins. It was her hunch that when we know more, we will see Melanesia 'as less a passive recipient of influences than an active participant in contact with a Southeast Asian world of islands, also poorly understood'. Like Egloff, she suspected prehistoric Melanesia had been 'a complex intercommunicating world' (Kennedy 1982: 27).

Egloff and Kennedy were way ahead of the rest of us working in the Pacific. The case in favour of their way of thinking about ancient geography in the southwest Pacific is growing: 1 Irwin (1992: 36-7) emphasizes that the islands of the Bismarck Archipelago are part of a great chain of archipelagoes stretching between Southeast Asia and the Solomon Islands. He believes anyone with a canoe in prehistoric times would have found no insurmountable barriers to travel back and forth along this chain. He argues that after people reached them, New Guinea and much of island Melanesia would have been integral components of an ancient voyaging corridor in the $\mathrm{Pa}$ cific, a canoe seaway running from eastern Melanesia all the way back to mainland Asia (Irwin 1992: 5-6, 19; Irwin et al. 1990).

2 Robin Torrence (1994) reminds us that people have not always been as settled in their ways as they may be today. Torrence, Specht and others report, for instance, that in the last 6000 years in the Talasea area 
of New Britain there has been a gradual but directional change in the way people exploited their environment. The management of resources intensified; people began to move around less often from place to place. Even then, Torrence finds, parallel changes in pottery over time suggest that as their spatial mobility declined, people kept in touch with one another over a large area of the southwest Pacific for quite some time (see Kirch et al. 1991: 160). In sum, there is reason to think Lapita pottery did not necessarily mark a period to increased interaction in the voyaging corridor c. 3500 years ago; nor did longdistance voyaging and exchange in the southwestern Pacific begin with the appearance of Lapita pottery in the archaeological record. On the contrary, if life became more settled during Lapita times, as some authorities maintain (e.g. Kirch 1987), then ties between people living at a distance from one another were probably becoming less immediate by then, less direct. Put simply, instead of marking the opening of beneficial connections between southeast Asia and Melanesia - and the beginning of an era of remarkable longdistance exchange (Kirch 1990; 1991) Lapita may have heralded the opposite trend (Kirch 1990: 128-30; but see Gosden \& Pavlides 1994)

3 Since 1987 we have been documenting social, economic and political connections among people on the Sepik coast of northern New Guinea since the turn of the century (Welsch et al. 1992; Welsch 1996; in press a; in press b; n.d.; Welsch \& Terrell 1991; 1994; in press). Even after thousands of years of settled community life, people participate in a remarkably extensive network of relationships that stretches for many hundreds of kilometres along this coast - and inland, too. Such relationships are conventionally glossed in anthropology as trade partnerships. We find they can be more accurately described, the way people on the Sepik coast do, as inherited friendships (Welsch \& Terrell in press; for a comparable example, see Harding 1967: 165-84). The 'experienced' social fields of individuals and communities on the Sepik coast can be likened to a very large playing-field with many groups of players, many different languages and several different local environments, each with its own economic possibilities. The metaphor of a playing-field is apt, for people on the coast, as in most sporting events, share an agreed-upon set of basic rules, expectations and organizing principles. Importantly, the complex infrastructure maintained by this traditional institution unites communities on the coast into a multi-ethnic configuration that might even be called a polity without (in pre-European times) an overarching political authority or governmental central place.

4 This resilient institution is an empirical example of what the anthropologist Lesser (1961: 43) called a social field of 'structured friendships'. One remarkable fact about this infrastructure is that people in the communities linked with one another along the $700 \mathrm{~km}$ of coastline included in our study area between Jayapura in modern Irian Jaya and Madang in Papua New Guinea speak a total of 60 different languages belonging to 24 different language families. Another remarkable fact is that the material culture of these many communities is, nevertheless, strikingly similar from place to place. So much so, that we have cautioned, by analogy, that the discovery of similar artefact inventories at Lapita pottery sites does not necessarily have to mean the people living at those sites had belonged to a single linguistic population, ethnic group or 'people' (Terrell 1989; Terrell \& Welsch 1990; Welsch 1996; Welsch et al 1992).

We think these several observations, taken together, suggest another way of looking at Lapita, a social field model (Terrell et al. 1997) that we call the voyaging corridor model. Recall that the Melanesian homeland model makes time relative but geography is still more or less determinate (TABLE 1). The voyaging corridor model lets both time and space be indeterminate:

\section{ASSUME THAT}

Temporal: When any particular cultural element associated with Lapita pottery first appeared in the Bismarck Archipelago is relative (it depends on which element one is talking about). 
Geographic: The extent of a given individual's social field (i.e. their 'social horizons') depends on - is relative to - their situation, motivations and personal relationships, both those they inherit and those they foster during their lifetime. In more abstract terms, an individual's social horizons may also be said to be relative to variables such as populations density, settlement and community patterning, subsistence activities and range, ease of mobility and transport, etc.

\section{THEN}

Voyaging corridor: Seen as an interaction sphere, the spatial dimensions and components of the voyaging corridor between Asia and the Pacific have undoubtedly varied with time and evolving circumstances.

Social fields: At the level of the individual, this interaction sphere has comprised an indefinite number of overlapping social fields, the horizons of which have also varied.

Network patterning: As Irwin $(1983 ; 1985)$ has shown for the Mailu and Massim areas elsewhere in Papua New Guinea, the centrality or marginality of communities within the voyaging corridor has undoubtedly also varied over time.

Settlement location: Around 18,000-20,000 years ago during the Last Glacial Maximum, the Pacific Ocean fell as much as $130 \mathrm{~m}$ below its present height (Dickinson 1995); sea levels have only been within a metre or two of their modern position for the last 6000 or so years (Dickinson et al. 1994; Gosden \& Webb 1994); before then, the shore-line in many parts of the voyaging corridor was not located where it is today and coastal peoples were probably not living near present-day beach locations until the mid Holocene (which is one reason it has been hard to locate archaeological sites older than Lapita).

Mobility: As communities became more fixed on the landscape after $6000 \mathrm{BP}$ and people ranged less widely to gather, harvest, or mine needed resources, interactions among people at a distance from one another became more indirect (trade and communication became more 'down-theline'; see Green 1987).

Subsistence: While it is sometimes said that the management of certain plants and animals (chiefly ones thought to be of Asian origin) permitted Lapita expansion beyond the Solomons after c. 3200 years ago (Allen \& Gosden 1996; Bellwood 1989b: 23; Gosden 1992; Spriggs 1989), it is likely that subsistence during Lapita times was normally based on a wide spectrum of food resources, both wild and carefully managed, rather than on a handful of (unidentified) domesticated species (Harris 1995; Yen 1995).
Pottery: The addition of pottery to archaeological assemblages in the voyaging corridor sometime after $c .6000$ BP greatly increased the visibility of some prehistoric sites on the landscape.

Lapita expansion: For reasons that Irwin (1992) has examined but which are mostly unknown, people making pottery (sometimes) decorated in the Lapita style (Butler 1994; Spriggs 1990) greatly expanded the range of human settlement eastward in the Pacific around 3000 years ago. Even then, 'we do not have a single integrated exchange system operating throughout Remote Oceania [specifically, the islands east of the Solomons as far as Fiji, Tonga, and Samoa] at the time of the Lapita horizon. Instead, we have a series of such systems, only loosely linked to one another by different imports or exports'. Moreover, Green sees a major break in these systems, 'so that imports and exports only rarely made it either way across the long water gap between Vonuatu and New Caledonia on the one hand, and the Fijian group' on the other (Green 1996: 126; also Green 1995). In other words, while people in the newly settled parts of the Pacific did not lose contact with people to the west of them, nobody thinks Lapita was an integrated kingdom, confederation, colonial empire or plantation system. Contrary to opinions sometimes voiced, Lapita was not a 'unity' (Spriggs 1993a: 187); not an 'extremely widespread system' (Kirch 1991: 158-60) or organized commercial network.

Processes of interaction: There is no evidence suggesting that processes of social and economic interaction among communities during Lapita pottery times were necessarily different from those that had been developing in the voyaging corridor prior to Lapita's popularity. There is no evidence showing that individuals were travelling much greater distances except where water gaps between islands made longer-distance voyaging necessary. The common statement that Lapita exchange networks 'have no known ethnographic counterparts' (Kirch 1991: 160) is unproven - assuming that one knows what such a statement would mean - except in the selfevident sense that Lapita pottery had an unusually wide distribution in the Pacific, and in the trivial sense that nothing today is quite like the way things were 3000 years ago. The Pacific anthropological literature is full of ethnographic case-studies that archaeologists interested in Lapita find useful (Torrence \& Summorhayes 1997).

Change: There is some evidence to suggest that social fields and exchange networks in the Pacific in the last 1000-2000 years have become somewhat more localized and, in some instances, 
more centralized than they were during late Pleistocene or early-to-middle Holocene times (Irwin 1992; Kirch 1991; Spriggs 1993a). There is no reason to think (except in those localities where specialized 'middleman' trade systems have developed in the recent past; see Kirch 1991) that processes of interaction between communities changed markedly with this retraction of social fields and trade networks.

\section{Empirical considerations}

As we have discussed, debate over the origins of Lapita pottery and the so-called Lapita cultural complex has become a 'mostly this, mostly that' debate - is Lapita 'mostly Melanesian' or 'mostly Asian' (e.g. Bellwood 1989a)? Unfortunately, deciding such a delicate issue is not helped by the marked disparity between the number of known Lapita sites and the very small handful of sites as old or older that lack Lapita pottery (pottery makes archaeological sites much easier to find in the tropics). Most experts now agree that Lapita pottery sites have produced direct evidence of arboriculture, indirect signs of horticulture of some sort, good evidence for the exploitation of littoral and marine resources (including fish, shellfish, turtles, and porpoises), some terrestrial hunting, introduced animals (pig, chicken) and settled village life, as well as the transfer of raw materials and finished goods, including pottery (Spriggs 1993: 192-3). What they do not agree on is whether this suite of traits was unique to the earliest Lapita sites in the Bismarcks. Without knowing what life was like at 'non-Lapita' sites, it is anyone's guess whether these presumed 'Lapita traits' were new to Melanesia at that time and, equally important, if their joint appearance at archaeological sites truly defines a culturally distinctive 'Lapita complex'. At present, no one is even sure how many of these traits must co-occur for any given site to qualify that site as a Lapita site. ${ }^{1}$ All these concerns

1 Lapita as a differentiable cultural complex is an unstable taxonomic unit which has not been (and evidently cannot be; see Green 1992; Kirch \& Hunt 1988; Terrell 1996) defined on the basis of uniquely shared innovations or a 'definite nucleus of associated traits' (Sapir 1916: 30), and which has never been described using rigorous multi-dimensional statistical clustering. For some, therefore, Lapita is merely 'an overarching cultural entity' standing for 'something more than a ceramic series, or even a cultural horizon, though it would probably not constitute a culture in the way that all-embracing term is frequently used' (Green 1992: 12). Some would extend the term Lapita to encompass early are critical, for what may actually be important about Lapita is not whether these traits originated in Asia or Melanesia but instead whether they co-occur (at least to begin with) only at Lapita sites. Said differently, even if all of these identified traits were present in Melanesia long before Lapita, their joint appearance at Lapita sites may be telling us that something new - something uniquely 'Lapita' - was going on at them, nonetheless.

Unfortunately the lack of comparable nonLapita sites dating to, say, 6000-3500 BP is not the only obstacle in the way of resolving the riddle of Lapita. The available site sample is not just imbalanced in favour of Lapita sites. Far too little is also known about several key geographic localities in the Pacific, such as Vanuatu, the Solomon Islands and northern New Guinea, The latter deficiency is especially critical, for as Golson has remarked on several occasions, the huge island of New Guinea and the Bismarck Archipelago together 'present a long northern coastline running west to Indonesia, open to receive and transmit cultural influences at all times during the sea-going era' (1982: 20; also Golson 1972a; 1972b). From New Guinea's geographic position, many have assumed that we would someday find the missing link between Lapita and Asia along this great island's northern shores (e.g. Green 1985: 220; Spriggs 1996b: 339). In Kirch's words, 'the search for Lapita origins must move westward along the unexplored north coast of New Guinea and into the Halmahera, Sulawesi, and southern Philippines region' (Kirch 1988c: 336; also Kirch 1988b: 158; Kirch 1997: 55).

\section{New Guinea research}

Before 1993, the only Lapita potsherd found on the New Guinea mainland - and the only Lapita sherd found west of the Bismarcks was a $7-\mathrm{cm}$ sherd recovered during the Sec-

plain pottery assemblages from the southeast Solomons and Samoa, aceramic assemblages from Nissan Island between the Solomons and New Ireland, Island Southeast Asian Neolithic assemblages, and even the earliest ceramic sites in the Mariana islands in western Micronesia (Spriggs 1996b: 341-2). Green, however, has outlined reasons for restricting usage of the term so that integrative historical connections - 'common origin, intermittent contact between otherwise unrelated cultural traditions, or through extensive trade and exchange, or some combination of these and other processes' - can be more readily discerned (1992: $12,13-14)$. 


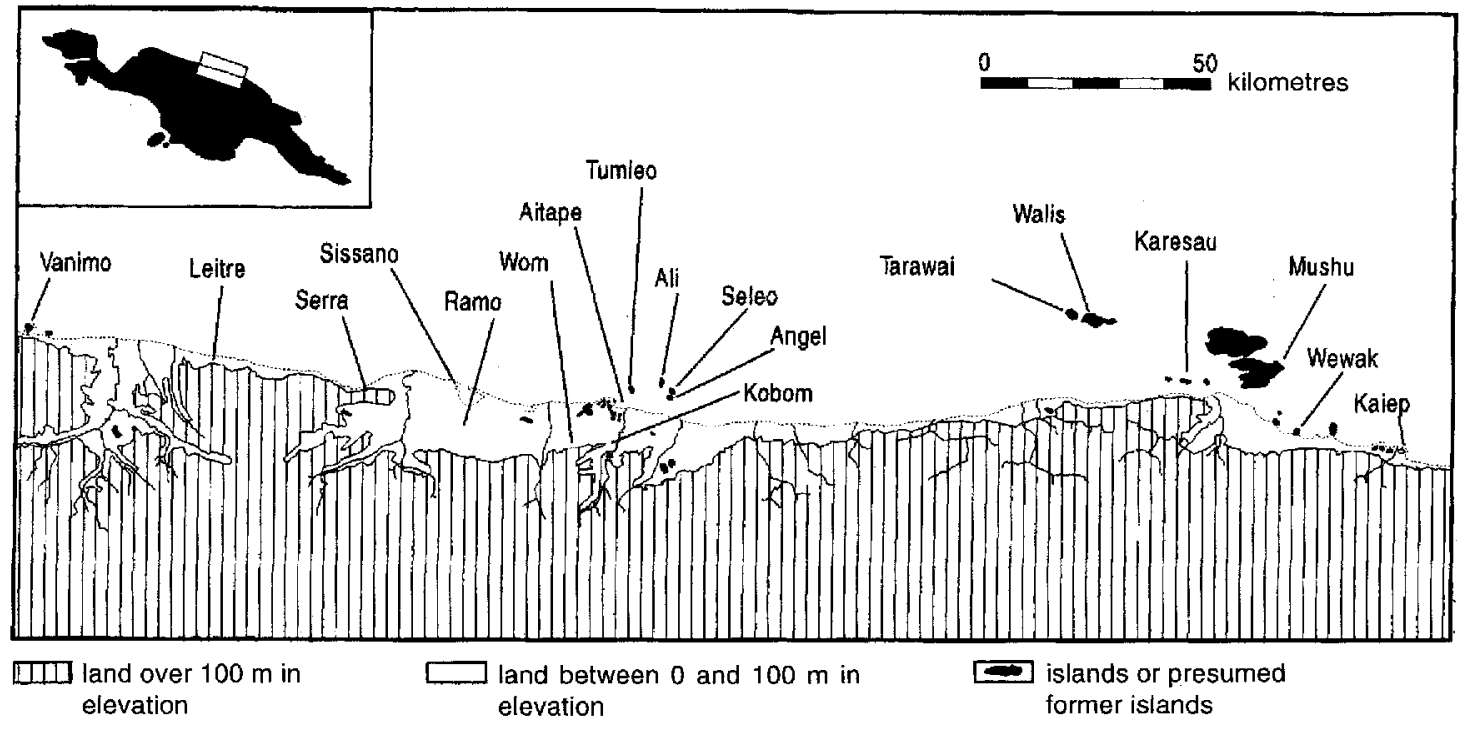

FIGURE 1. Sepik coast of Papua New Guinea. (Jack Scott \& Zbigniew Jastrzebski.)

ond World War from an unknown location somewhere in the Aitape district of Sandaun Province (Swadling et al. 1988). Brief archaeological surveys conducted in the 1980s by the Papua New Guinea National Museum in the Aitape and Wewak areas and on the offshore islands of Tumleo, Kairiru and Muschu (FIGURE 1) had not found Lapita sites anywhere along Papua New Guinea's northern coastline (Swadling 1990: 76; pers. comm.).

We were on the Sepik coast between March 1993 and February 1994 studying how exchange relations integrate local communities into larger social fields. We obtained extensive information (through informant interviews and participant observation) on the raw materials, manufacture, use, cultural meaning and local socio-economic significance of this region's material culture. We went to over 80 villages in some 42 communities in Papua New Guinea and 11 villages in and around Jayapura. We collected contemporary material culture (some 2000 items) in nearly all of these communities, with important collections from about 30 communities.

Soon after we had arrived on the coast in 1993, we realized that the ease with which we were able to move between the coast and offshore islands in our 6-metre outboard dinghy gave us an unparalleled chance to survey the area archaeologically as well as ethnographically. We discovered also that surface finds were numerous (potsherds, obsidian, chert, worked shell, etc.), varied and often distinctively unlike archaeological assemblages reported from elsewhere in New Guinea. The results of our survey work can be briefly detailed. Our site roster includes 121 collection areas (and find spots). We recovered 10,644 potsherds, 1472 obsidian flakes ( $1.5 \mathrm{~kg}$ ), 75 chert flakes, 23 pieces of worked shell, 10 whole or fragmentary stone or shell adzes/axes, and a smaller number of other materials (beads, modern glass and ceramics, metal, etc.). Most of these finds come from sites on Tendanye (Tarawai) and Walifu (Walis) off the coast near Wewak; Tumleo, Ali, Seleo and Angel off the coast at Aitape; and the mainland Serra district west of Sissano Lagoon (FIGURE 1). All of the finds were catalogued and studied by Terrell at our field headquarters on Ali Island. The ceramic assemblages were then sampled for later laboratory study in the United States. The obsidian finds were loaned by the National Museum of Papua New Guinea to the Field Museum for further study.

\section{Pottery}

We found only one Lapita potsherd (FIGURE 2) in the area we surveyed between Wewak and the Serra district, from a small surface collection we made at a locality called Tubungbale on the raised (c. 1-2 $\mathrm{m}$ ) marine terrace at the back of the modern (beach) village area on the east side of Ali Island. While this sherd is too 
small to identify the design represented, the dentate-stamping is finely executed in the manner usually associated with early Lapita vessels (Terry L. Hunt pers. comm.). The fired clay body is $0.8 \mathrm{~cm}$ thick, reddish, friable, poorly compacted and has a fine calcareous temper. ${ }^{2}$

While Lapita pottery is notable for its rarity on the coast, other styles of prehistoric pottery are abundant in the local archaeological record. On the basis of our field and museum-based studies, we have constructed pottery sequences (see Spriggs 1996a: 43; 1996b: 334) for the Wewak (i.e. Tendanye/Walifu), Aitape and Serra localities that help fill in research gaps between Paul Gorecki's results from the Vanimo area close to the Irian Jaya border (Gorecki 1992; Gorecki et al. 1991) and Pamela Swadling's pioneering work in the Sepik-Ramu basin (Swadling et al. 1991; Swadling \& Hope 1992). These new ceramic sequences are provisional and require further testing and excavation.

Swadling (Swadling et al. 1989; Swadling \& Hope 1992: 36) and Gorecki (Gorecki 1992; Gorecki et al. 1991) have argued from their archaeological studies that pottery-making in northern New Guinea pre-dates the first appearance of Lapita pottery in the Bismarck Archipelago by some 2000 years. Unfortunately the radiocarbon dates for early pottery, obsidian, etc. at Swadling's Akari site are inconsistent. Although some of the dates suggest pottery appeared in the Sepik region about 5500-5600 years ago, one date (uncalibrated) on a composite charcoal sample of $3280 \pm 200$ b.p. (ANU7085) and another of $1630 \pm 120$ b.p. (ANU-7081) have raised doubts about the antiquity of the associated pottery and other artefacts (Swadling et al. 1991: 106). Spriggs (1996a; 1996b: 329) argues that the pottery finds at these sites are much younger than their reported ages: the

2 The design elements are (1) a narrow, 3-row linear-dentate band, a 'linear juxtaposed continuous triple' band in Siorat's (1990) terminology; (2) a parallel, single linear row of dentatestamped lunettes, (3) evidently a parallel, single row, linear-dentate band 'linear juxtaposed continuous single'; and (4) another parallel row of lunettes the arch of the one well-preserved lunette curves in the same direction as those in the more intact row and its position suggests these rows in Siorat's terminology, were 'superimposed'). Except for the linear-dentate row between the lunettes, this configuration suggests that the design pattern may have been something like the top and bottom marginal zones of Siorat's illustration of 'linear oblique composite decoration' (1990: plate 3), although the design elements on this Aitape specimen are smaller and have finer details.

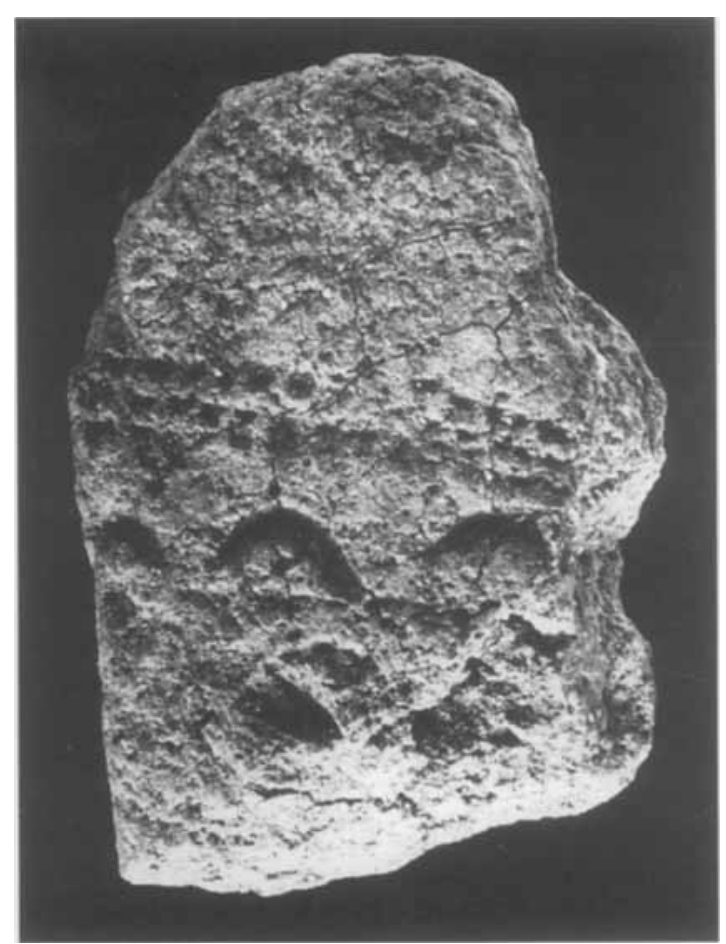

FIGURE 2. Lapita sherd, Tubungbale, Ali Island. $2 \cdot 2$ cm max dimension. (C) The Field Museum, Chicago (IL). Photo John Weinstein, Neg. \#A112899.)

sherds recovered had worked their way down from higher stratigraphic levels.

In the late 1980s, Swadling and others from the National Museum in Port Moresby found potsherds on the hills around Aitape, as we did during our first reconnaissance work in the area in 1990 (Welsch \& Terrell 1991). These surface finds were usually quite fragmented and eroded. In 1993-4 we discovered that most of the pottery types in surface collections made on the near-by islands do not occur in collections made on the Aitape hills. Instead, most of the sherds found at Aitape come from small, evidently round-bottomed, low-fired vessels having thin $(c .0 \cdot 3-0.6 \mathrm{~cm})$ body walls and fine, white temper inclusions (quartz and feldspar). While the sherds were often eroded, it was possible to tell that at least some of the pots were red-slipped; rims are simple and usually unnotched; the vessels are basins, bowls and everted-rim pots; surface decoration is rare and is limited to impression and surface scoring 



FIGURE 3. Pottery sherds from Sumalo Hill, Aitape district. (Drawing Zbigniew Jastrzebski.)

done with small-tool and pronged ('dentate') implements (FIGURE 3: 1-6). At first, we suspected that carved paddles might have been used in some instances (e.g. FIGURE 3: 5-6); closer study showed that the complex designs sometimes evidenced were achieved by multiplescoring rather than paddle-impression. Terrell has named this simple style of mostly undecorated (but sometimes burnished) 'red-slip' ceramics Sumalo Ware after a collecting locality on Sumalo Hill near the mouth of the Raihu
River on the east side of Aitape. Radiocarbon determinations (FIGURE 4) suggest that Sumalo ware dates back to $C$. $1280-1170 \mathrm{BP}$.

In summary, our survey work in 1993-4 led us to the inference that Lapita pottery is nearly absent on the Sepik coast of northern New Guinea and that other pottery traditions in this region may be as old or older than Lapita. We tentatively concluded that the ornate Lapita style found in the Bismarck Archipelago and farther to the east in the Pacific was only one of sev- 
FIGURE 4, Calibrated radiocarbon determinations for charcoal samples associated with Sumalo (NGRP-23, St Martin's) and Tumleo Island (NGRP-46, Sapi hamlet, samples marked *) plotted using $\mathrm{OxCal}$ Program v2.18. ISGSare independent laboratory determinations run on sub-samples of the same field sample from NGRP-23; ISGS-3656 is a recount of ISGS-3652. ware pottery at Aitope 3652 and Beta-105671



eral related, but not identical, early ceramic styles in Irwin's voyaging corridor between Asia and the Bismarck Archipelago. As Solheim (1964), Golson (1972a: 577-81), and others anticipated, these traditions may alike be members of a widely distributed technological style of ceramic industries in the western Pacific marked - roughly speaking - by the presence of plain and red-slipped globular pots (Bellwood 1985: 223-8, 252-3; 1992; 50-51; Bellwood \& Koon 1989: 618, 621; Butler 1994; Spriggs 1989: 605-9; 1993: 193), ${ }^{3}$

\section{Obsidian}

Obsidian from sources in the Bismarck Archipelago has previously been reported from archaeological contexts on the north coast of New Guinea by several investigators. Five pieces, Swadling notes, found at Cape Moem east of Wewak have been sourced as coming from Lou Island, and five of six specimens found at Wom just west of Wewak also derive from the same source; the other specimen is from the Talasea area of northern New Britain (Swadling 1990:

3 The first archaeological excavations in the Aitape area have now been done (September-Octaber 1996) by a team led by Terrell, Glenn Summerhayes (LaTrobe University) and Baiva Ivuyo (PNG National Museum). Detailed laboratory studies are in progress.
86, n. 7). Gorecki and his colleagues found numerous surface finds of obsidian flakes during surveys on the coast in 1988 and 1989 between Leitre and the Irian Jaya border, all thought to have come from Lou Island (Gorecki et al. 1991: 119). They found little obsidian, however, in stratigraphic contexts during their excavations in June-July 1990 at three rock-shelters in the Musu-Fichin locality $18 \mathrm{~km}$ west of Vanimo (Gorecki pers. comm.).

Sourcing of 45 obsidian samples collected in 1993-4 by Glenn Summerhayes at the laboratories of the Australian Nuclear Science and Technology Organization at Lucas Heights, Australia, used PIXE-PIGME analyses (TABI.E 2). The obsidian examined was found to come from sources in the Bismarck Archipelago: from the Kutau source near Talasea on the Willaumez Peninsula of New Britain, from Pam Lin (Pam Island) and from Umrei and Wekwok (Lou Island) in the Admiralty Islands (Summerhayes pers. comm). The results of relative density analysis of all the obsidian finds using a calibrated solution of sodium metatungstate are shown in TABLE 3 . While this method of assay is not foolproof (Torrence \& Victor 1995), these results indicate that the apparent absence of obsidian from West New Britain sources on Tandanye Island suggested by PIXE-PIGME assay 


\section{source \\ find-spot locality}

Kobom

Ali Island

Tandanye

Talasea,
New Britain
Kutau

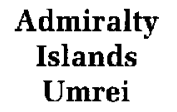

$4 \quad 3$

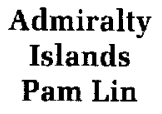

3

3

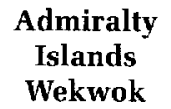

5

7

9

\section{Admiralty \\ Islands \\ unknown}

$\begin{array}{ll}3 & - \\ - & 1 \\ 2 & 1\end{array}$

TABLE 2. The results of PIXE-PIGME obsidian analyses.

\begin{tabular}{lrrrrr} 
source & $\begin{array}{c}\text { West New Britain } \\
\text { number }\end{array}$ & $\%$ & \multicolumn{2}{c}{ Admiralty Islands } & total num \\
find-spot locality & & & & & \\
Aitape & 1 & 12 & 7 & 88 & 8 \\
Ali Island & 92 & 19 & 395 & 81 & 487 \\
Ali Island (early?) & 16 & 26 & 25 & 73 & 34 \\
Karesau Island & 9 & 26 & 25 & 73 & 34 \\
Kobom (carly?) & 33 & 36 & 59 & 64 & 92 \\
Muschu Island & 0 & - & 3 & 100 & 3 \\
Seleo Island & 2 & 15 & 11 & 85 & 13 \\
Tandanye Island & 58 & 29 & 143 & 71 & 201 \\
Tandanye (early?) & 133 & 43 & 178 & 57 & 311 \\
Tumleo Island & 2 & 6 & 32 & 94 & 34 \\
Walifu Island & 26 & 16 & 139 & 84 & 165 \\
Aiser & 0 & - & 1 & 100 & 1 \\
totals & & & & & \\
\end{tabular}

TABLE 3. The results of relative density analysis of obsidian flakes.

is probably an artefact of the small samples so far examined in that more exacting way. When the obsidian we collected in 1993-4 is stratified by site and ceramic associations as well as by locality, there is also a suggestion that the availability of obsidian from West New Britain sources changed over time. Our current hypothesis is that at some point in the past, the Admiralty Islands became the dominant or only source available to people on the Sepik coast. If this suspicion is confirmed by excavation, this pattern will be similar to that reported by Kirch and others for the Mussau (St Matthias) Islands east of the Admiralty Islands where Lapita sites have obsidian from both sources in roughly equal proportions, whereas Admiralties obsidian dominates in later occupations (Kirch et al. 1991: 157).

Analysis of the obsidian by weight (TABLE 4) shows that the average size of a flake may decline both with time and with distance from the sources in the Bismarck Archipelago. The observed difference between the average size (weight) of obsidian flakes found at Kobom on the mainland and from seemingly more recent sites on Ali Island contrasts with the similarity of the Kobom specimens in this respect to those from Wewak area sites (which are closer to the Bismarck Archipelago) may show that people in the Aitape area were once more directly connected to the Bismarck Archipelago than they were later in prehistory (see Torrence 1986). A decline in obsidian importing and utilization over time has also been reported for the Mussau Islands (Kirch et al. 1991: 157-8).

\section{Chert}

Research at Yombon in the interior of West New Britain has established that by 35,000 b.p. people had discovered and were using local sources of chert in Papua New Guinea (Pavlides \& Gosden 1994: 606). Most of the several thousand stone artefacts excavated by Gorecki and his colleagues in the Musu-Fichin locality west of Vanimo were made from fine-grained chert presumed to have been obtained from local limestone exposures (Gorecki et al. 1991: 120, 121). We found worked chert flakes at numerous locations on the coast and offshore islands in 
1993-4. Our excavations in 1996 have now established that chert and obsidian were both worked at Sumalo Period sites in the Aitape area, with chert evidently more common than obsidian. Preliminary analysis of stone excavated in 1996 indicates that the chert may all be chalcedony derived from coral limestones and possibly tuff silicified by rhyolitic vulcanism (Peter Sheppard pers. comm.). If all of the chert was formed by this geological process and is, therefore, mineralogically (and in its fossil content) homogeneous, it will be difficult to determine specific source locations (see Sheppard 1996).

\section{Worked shell}

Lapita sites frequently evidence a wide variety of artefacts made of shell, including fishhooks, scrapers, pendants and Conus, Trochus, Tridacna and Spondylus rings, discs, beads, etc. (e.g. Kirch 1987; 1988a; Poulsen 1987). Often the forms recovered are comparable to implements and ornaments from many parts of Oceania documented ethnographically in $\mathrm{mu}$ seum collections. Kirch (1988a), Spriggs (1993) and others have suggested that such characteristic elements of Oceanic material culture were Lapita introductions, as distinctive and diagnostic of the Lapita cultural complex as Lapita style pottery. Others who contest this evaluation place the roots of such elements of material culture further back in time in Oceania than Lapita (Smith 1995). In 1993-4 we found a small number of edge-ground Tridacna shell adzes/ axes and arm-rings (both unifacially and bifacially cored). Such arm-rings are still being manufactured on Tandanye Island. In addition, we recovered a small $(3 \cdot 4 \times 2 \cdot 0 \times 0 \cdot 1 \mathrm{~cm})$, broken rectangular pendant (FIGURE 5) of indeterminate shell at Tubungbale on Ali Island where the Lapita sherd was found. As far as we can tell, such a pendant would not be out of place in a Lapita site assemblage, although we have found no exact equivalents in the literature. Our excavations in 1996, however, recovered little evidence of shell-working until late in prehistory.

\section{Discussion}

Since the Lapita Homeland Project in 1985, a number of archaeologists have looked for signs of Lapita in eastern Indonesia and along the Sepik coast of Papua New Guinea. To date,

$\begin{array}{lrcc}\text { locality } & \text { number } & \text { mean weight }(g) & \text { s.d. } \\ \text { Kobom } & 118 & 1.56 & 1.79 \\ \text { Aitape } & 609 & 0.50 & 1.25 \\ \text { Wewak } & 745 & 1.38 & 3.35\end{array}$

TABLE 4. Analysis of 1472 pieces of obsidian by weight $(F$-ratio $=22 \cdot 237)$.

however, those who favour the Asian homeland model can point only to generic, not specific, ties between Lapita assemblages in Melanesia and early ceramic assemblages in eastern Indonesia (Bellwood 1997a: 234-6; Kirch 1997: 47-52; Spriggs 1996b). Ironically, the best evidence for Lapita west of the Bismarck Archipelago adds up to only two potsherds from Aitape. We suspect these sherds came to the Aitape district the same way as the obsidian found at many locations along the Sepik coast - through trade or exchange - and from the same general direction, the Bismarck Archipelago. In a word, the argument that Lapita was a 'pre-packaged' cultural complex that was carried along New Guinea's northern coast-line from somewhere in Asia and introduced readymade into the Bismarcks (perhaps at Mussau?; see Kirch 1987: 177; Kirch et al. 1991: 159-60) is premature. The lack of substantiating evidence, however, does not mean the alternative Melanesian homeland model is necessarily the better solution to the riddle of Lapita. If these two models were the only likely ones, picking between them would have to be tabled for insufficient evidence in both cases.

We are currently studying the archaeological finds we excavated at Aitape last year. As one result of our survey in 1993-4, we returned to Aitape in 1996 with the hypothesis that the Aitape ceramic sequence begins with Sumalo ware - a distinctive kind of pottery with technical and some stylistic affinities both with Lapita pottery in the Bismarck Archipelago and with early as well as not-so-early ceramics in the voyaging corridor west of Aitape: specifically, the Bird's Head region of western Irian Jaya and Gebe Island as well as the northern Moluccas (e.g. Uattamdi rock-shelter, Kayoa Island; Bellwood 1992; Irwin pers. comm.), the Talaud Islands (e.g. Leang Tuwo Mane'e shelter; Bellwood 1976; 1985: 227-8) and Timor (Glover 1986). Comparable pottery has also been found in western Micronesia where it is as old as Lapita - even though it is clearly not Lapita 


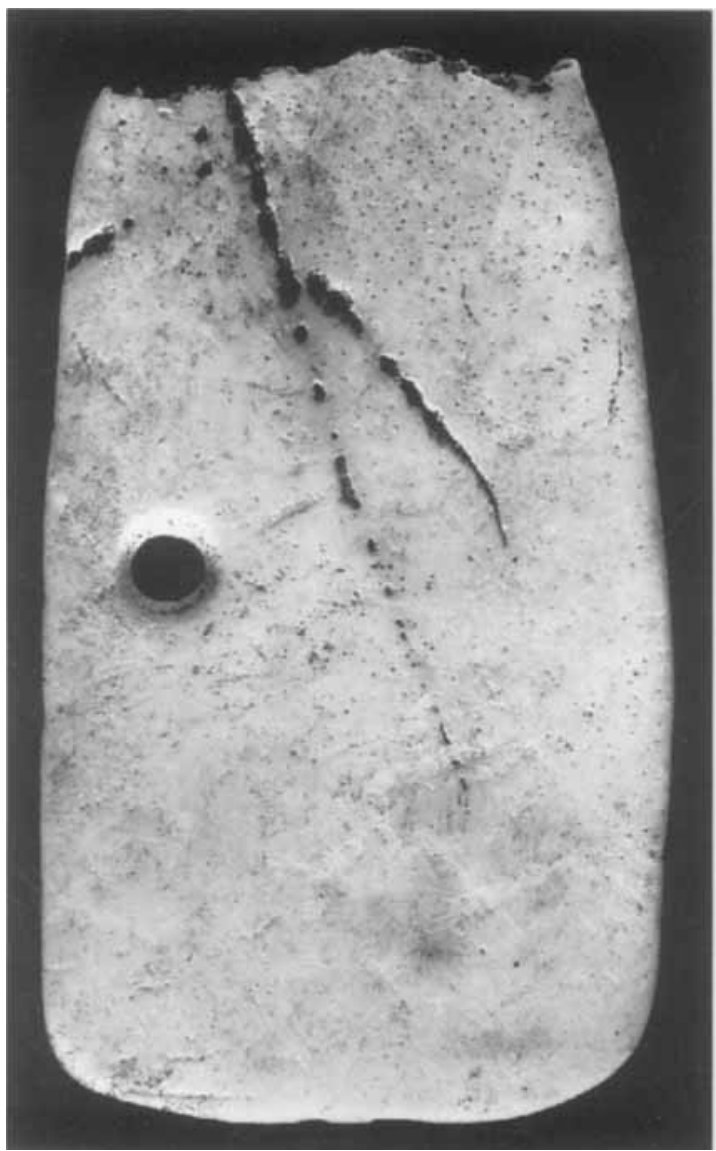

FIGURE 5. Shell pendant, Tubungbale, Ali Island. $3.4 \mathrm{~cm}$ max. dimension. (C The Field Museum, Chicago (IL). Photo John Weinstein, Neg. \#A112902.)

pottery (Butler 1994). Our stratigraphic excavations on Tumleo Island and at Aitape in 1996 confirmed our working hypothesis: potterymaking at Aitape begins with Sumalo.

Our extensive survey work in 1993-4 made it difficult for us to see Lapita-style pottery with its complex vessel forms and ornate decorative motifs - as the precursor of plain, impressed and scored Sumalo ware. We also hypothesized, therefore, that Lapita pottery and Sumalo ware may have been contemporary local styles of prehistoric red-slipped pottery in Irwin's voyaging corridor between Asia and the Bismarck Archipelago. Radiocarbon dating has now established that Sumalo ware is younger than Lapita pottery and it is evidently contemporary with Metal Age sites in Indonesia (Swad- ling 1996: 272-4). Our second hypothesis was wrong.

Pacific archaeologists, long suspecting that the 'red-slip' industries of western Melanesia are directly related to one another (Allen 1972; Bellwood 1978a: 282; Bulmer 1996; Craib 1983; Kirch 1995; Spriggs 1989b: 607), have usually seen these industries as younger versions of Lapita ware on the assumption that all pottery in Oceania is 'Lapita-derived' (Bellwood 1978a: 255-6). However, the similarities among Lapita ware (c. $3200 \mathrm{BP}$ ), Sumalo ware (c. 1280-1170 BP) and 'Early Period' (c. 2000-1000 BP) redslip ceramic assemblages on the southern coasts of New Guinea once again are generic, not specific (Bulmer 1996). To paraphrase Irwin \& Holdaway (1996: 225), there are unexplained gaps in time, space and style. Viewed collectively as a 'family' of ceramics or as a technological style, they give credence to the idea that Irwin's voyaging corridor has been an interaction sphere for at least the last 4000 years. But the differences among these pottery industries are evident enough that it is anyone's guess how they may be historically related to one another. It is as difficult to relate these industries unequivocally to one another as it is to relate any of them to comparable industries in eastern Indonesia and western Micronesia.

A date of around 1150-1300 years ago for Sumalo pottery at Aitape is not inconsistent with the linguistic hypothesis that the presence of Austronesian (Oceanic-speaking) settlements in northern New Guinea (Ross 1988; 1989; 1991) attests to east-to-west movements of people at different times from somewhere in or near the Vitiaz Strait between New Guinea and the Bismarck Archipelago in the last 2000 years (Spriggs 1996b: 339). If this hypothesis were correct, however, we would have thought that Sumalo ware would look like ceramic industries of comparable age found archaeologically in the Vitiaz Strait and northeastern New Guinea areas. Based on what is presently known about these parts of New Guinea (Lilley 1986), this is not the case. Sumalo ware far more closely resembles undecorated Lapita wares and the early red-slip industries of eastern Indonesia and southern New Guinea than anything thus far discovered in the Vitiaz Straits region. We are, however, sceptical of the additional claim (Ross 1988: 123 ; 1991) that the distribution of Austronesian languages along the Sepik coast shows the 
most probably chronological sequence of a succession of settlement moves; nor does our ethnographic information support the contention that before European contact, Austronesian-speaking communities on the Sepik coast were more regularly in contact with one another than with their non-Austronesian-speaking neighbours (Ross 1991: 448).

Contemporary societies in New Guinea are famous in the ethnographic literature for engaging 'in an import and export of ritual and artistic culture that reaches intensities almost unparalleled in the nonindustrial world' (Roscoe 1989: 219). Our predecessor, A.B. Lewis, observed first-hand the transmission of carving styles along the Sepik coast in 1909; our own ethnohistorical data show that pottery-making and other craft techniques have also been moving from village to village along the coast. In this light, the assertion that all pottery industries in Melanesia are Lapita-derived may be an historically empty statement. As the evidence stands, this claim is largely a non-explanation of the similarities and differences among these diverse pottery industries. We see a pattern in this diversity, nonetheless. Like Lapita itself, each of these red-slip industries seems to arrive in its respective locale fully formed and as if from nowhere in particular. In spite of their generic 'family' resemblances, the stylistic and chronological differences among the earliest redslip assemblages in different coastal parts of western Melanesia apparently indicate that the art of pottery-making was imported and exported in prehistoric times in differing ways. And it may be extremely difficult after the fact to reconstruct these varied historical pathways of transmission and change. Our own current working hypothesis is that Sumalo ware signals the arrival of pottery-making people who came from somewhere to the west of Aitape, not from the Vitiaz Strait. Soon afterwards, however, these settlers were drawn into increasing trade and communication with people to the east of them - as evidenced by the transfer of obsidian from the Bismarcks and the appearance of pottery styles (incised and appliqué) at Aitape that have widespread parallels elsewhere in Melanesia.

We also distrust the statement that it was their 'agricultural economy' that gave Lapita people 'the necessary demographic muscle' (Spriggs 1989: 608; also Spriggs 1993a: 193-4) to invade Melanesia and press on to Polynesia. John Chappell (summarized in Chappell 1993), Swadling (Swadling 1990; 1996; Swadling \& Hope 1992; Swadling et al. 1989; 1991) and others have shown that around $5000-6000$ years ago when the waters around New Guinea had risen after the Pleistocene to near their present level, the basin of the Sepik River as far upstream as Lake Chambri east of the modern government centre at Ambunti was a great inland sea. Since then, this mid-Holocene sea has silted up and the river has taken its place. While details are not yet certain, the Sepik coast was also different back then. At Aitape, the shoreline was somewhere near the foot of the present 80-100 m contours (FIGURE 1) well to the south of its current position. Over the last 6000 years, the coastline has advanced northward, a gradual process of progradation and infilling still in action in the changing modern lagoonal systems behind the beach at Malol, Sissano, Serra and elsewhere on the coast.

Six thousands years ago there were two different kinds of coral islands off the Aitape coast: high (up to $100 \mathrm{~m}$ above sea-level), steep, upraised reefs of Pliocene/Miocene age situated near the old shore-line; and flat, slightly elevated Recent coral platforms farther offshore (Haantjens et al. 1972). The latter, still extant, are Tumleo, Ali and Seleo islands. The former, now captured by the advancing shore-line, comprise the steep hills around and west of Aitape. An extensive series of prograding beach ridges behind the strand east of Aitape abuts these hills - one of which is locally called Sumalo - and runs parallel to the coast. When they were first incorporated into the advancing shore-line, Sumalo Hill and the other upraised reef crests near by evidently formed the elevated headland of a peninsula. Such 'captured' headland peninsulas can still be seen on the coast near Wewak and Vanimo. Preliminary sub-surface coring in 1996 established that blue-grey clays thought to indicate former lagoonal swamps can be found at a depth of about $3 \mathrm{~m}$ at Aitape and at the base of the foothills inland. Woody material extracted from this stratigraphic layer has been dated by AMS assay to $c$. 6000-5750 years ago (Beta-105207, $5190 \pm 40$ b.p.). It is likely that by then infilling on the western side of this headland peninsula had created an extensive lagoon, or series of lagoons, that has now been completely filled in - except for the remnant la- 
model

type

process

agency

duration

distribution Taiwan to eastern Polynesia

driving force population growth, the Neolithic arts

\section{Melanesian homeland}

evolutionary

local development and colonization

Lapita cultural complex

c. $3500-2500 \mathrm{BP}$

Bismarcks to eastern Polynesia

wanderlust?, exploration as a cultural norm? voyaging corridor

historical

interaction, settlement expansion

individuals, social groups

variable and situational

overlapping social fields

post-Pleistocene environmental change and other circumstances, mostly undocumented

\begin{tabular}{|c|c|}
\hline phases & $\begin{array}{l}\text { some elements of Lapita } \\
\text { culture arose during a } \\
\text { pause in the Bismarcks; } \\
\text { basic Polynesian } \\
\text { innovations developed } \\
\text { during a pause in western } \\
\text { Polynesia }\end{array}$ \\
\hline
\end{tabular}

basic Polynesian innovations developed during a pause in western Polynesia

TABLE 5. Key ingredients of three Lapita models.

goons at Sissano, Malol, etc. In short, as elsewhere in the Indo-Pacific (Clark 1991; Dickinson 1995; Dickinson et al. 1994), the Sepik coast has changed markedly during the Holocene.

Today the lagoons at Sissano and elsewhere are complex, highly productive habitats (fish, shellfish and extensive mangrove-and-sago swamps) that support the largest village communities on the coast. Although it is commonly said that the domestication of certain plants (notably, ones of Asian origin) fuelled a Neolithic expansion eastward from Asia around 35004000 years ago (Bellwood 1996; 1997a; Gosden 1995; Spriggs 1989: 607, 609), we now think there was a more elaborate 'engine of change' at work at that time. The newly formed Holocene lagoons along New Guinea's northern coastline (and elsewhere in the voyaging corridor?) may have become productive enough to support major population growth with or without closely managed ('domesticated') plant and animal resources (Bailey \& Parkington 1988). To draw an American analogy, perhaps it was not so much plant domestication (like corn in central America) that led to prehistoric culture change in Irwin's voyaging corridor after 6000
BP as a naturally increasing abundance of certain wild foods (like salmon runs in the rivers of western Canada \& the United States).

Swadling and her colleagues (Swadling 1990; Swadling \& Hope 1992) have discussed the challenges that people faced in the Sepik basin after $6000 \mathrm{BP}$ as the inland sea grew smaller and living conditions deteriorated. We would stress instead that population growth along the Sepik coast consequent to the growth of lagoonal systems there may have expanded local social and economic horizons in all directions, especially eastward toward the Bismarck Archipelago and westward to island southeast Asia.

There is little solid evidence of significant human occupation on the southern coasts of New Guinea before c. $2000 \mathrm{BP}$ and the first appearance there of Early Period red-slip pottery. In marked contrast, research by Gorecki has demonstrated humankind's presence on the Sepik coast before 35,000 b.p. (Gosden 1995: 810; Gorecki pers. comm.); and both Gorecki and Pamela Swadling have established that there was significant pre-ceramic occupation of the Sepik lowlands at least by 6000 years ago. Whatever will finally be said about their 
evidence for pottery in the Sepik region predating Lapita in the Bismarcks by $c .2000$ years, our work at Aitape supports Gorecki's (1992: 28-30) suggestion that some kind of cultural or social 'fence' largely kept people living on New Guinea from mastering the art of potterymaking, or even importing Lapita pottery, until after the disappearance of the Lapita style as a particular art form in the Bismarck Archipelago.

Giving Gorecki's hypothesis historical depth and meaning will be a challenging task. It once seemed obvious to many that Lapita had been kept out of New Guinea because migrant Lapita people were Neolithic voyagers who kept to themselves on small off-shore islands or on sandy beaches on some of the larger islands where they had ready access to the sea; in contrast, it was thought that the native peoples of New Guinea were living then as huntergatherers in scattered bands and evidently could not use, could not appreciate, or were perhaps even openly hostile to the idea of cooking in pots. However, while the evidence may be scarce and scattered, it now seems likely that people in the voyaging corridor and even in the highlands of New Guinea had started to shift from being foragers to managing their food resources as early as $9000 \mathrm{BP}$ (Bayliss-Smith \& Golson 1992; Hope \& Golson 1995; Yen 1990; 1995).

Nowadays, therefore, it is common to say that Southeast Asia and New Guinea were both 'early and independent centres of agricultural development' (Bellwood 1996: 293; also Spriggs 1989: 608; 1996b). Early perhaps, but not independent. As Hather (1992: 70-71) wrote several years ago, 'the hypothesis that the subsistence structure of the Pacific is a relict of Southeast Asian origin, transferred to Melanesia and Polynesia prior to the widespread use of rice on the mainland, has recently been reassessed... . The part that New Guinea has played in the formation of subsistence strategies across the whole of the Pacific may therefore be of greater importance than has previously been realized' (Hather 1992: 70-71; also Kirch \& Weisler 1994: 293-5). This observation is an understatement (e.g. Yen 1990): while few today would question the composite Asian-New Guinean roots of Pacific Island subsistence strategies, there is little about 'agriculture' in Oceania that is unambiguously Asian or Southeast Asian in origin other than pigs, dogs, chickens and Dioscorea yams.
We would add three further observations. First, it is anyone's guess how decisive a role managed plants and animals played in the lives of Pacific Islanders in the past - that is, how 'horticultural' or 'agriculturalist' they were. The diversity of subsistence strategies still practised in the Pacific today makes the characterization of what was or was not a managed subsistence economy in prehistoric Oceania especially problematic (Bourke 1990). As Kirch \& Weisler (1994: 293) note, 'indigenous Oceanic economies were - with rare exceptions - founded on a dual horticultural-marine exploitation subsistence base, although the range of variation in the mix of specific strategies seems virtually boundless'. We think an important lesson can be drawn from this seemingly boundless diversity. Ecologists and evolutionary biologists like to distinguish between 'facultative' and 'fixed' or 'obligate' characteristics, responses and adaptive behaviours (Williams 1966: 80-83). The historically interesting question about prehistoric subsistence in Oceania is not how intensively people using Lapita pottery were 'Neolithic', but how often and how soon did their wild resources and those of their neighbours become exhausted (see Anderson 1996). And, therefore, where in the Pacific and how soon were they obliged to 'act like horticulturalists'.

Second, the evident rapidity with which the art of making Lapita pottery travelled from the Bismarck Archipelago to western Polynesia and both Vanuatu and New Caledonia in southern Melanesia makes it difficult to see 'the Lapita expansion' as a necessitated response to population pressure arising from the domestic arts of plant cultivation and animal husbandry. While it is sometimes useful to reduce the dynamics of history to summary notions such as population pressure or carrying capacity, these are shorthand explanations, not sufficient ones. When such explanations are unpacked and looked at closely, one should expect to find, among other things, that human cognitive processes of goal-setting, planning, decisionmaking, collective action and the like must have been part of what happened even in instances when people were actually 'responding to population pressure.' And in the case of Lapita, as Geoff Irwin (1989; 1992: 41, 61, 210-13) has argued on numerous occasions, 'being Neolithic' may have had little to do with 'getting there' and probably played a mixed and variable role in 'being there'. 
Third, Matthew Spriggs \& Christopher Chippindale (1989) once looked at Lapita's distinctive artistic expressiveness and widespread geographic distribution in the Pacific and asked rhetorically, "What human and social phenomenon is encoded in that pattern of material culture?' Based on what has now been learned about the production and use of the oldest Lapita pots from the Bismarcks Archipelago and New Caledonia (Ambrose 1997; Kirch 1997: 142-50; Summerhayes 1996), it is plausible that potterymaking in Melanesia was not just seen at the beginning as a technological breakthrough of utilitarian value (put simply, the idea that pots are great for cooking and handy to put things in). We suspect the art of pottery-making took so very long to reach mainland New Guinea because Lapita pots were culture elements in the material paraphernalia (Sapir 1916: 15-25) of some kind of cult, dance complex or social ritual (for a classic ethnographic example, see Bateson 1936). If so, does the discovery of Sumalo pottery at Aitape - so Lapita-like in its technology, vessel shapes, rim forms and so on, but which dates to a time so long after the end of Lapita in the Bismarcks - signal the survival of this cult, complex or ritual? Or had the art of pottery-making by then escaped from these associations and become just useful technology? Or alternatively again — as we suspect may be more likely - did the art of Sumalo pottery-making come from somewhere in western New Guinea or eastern Indonesia where people had kept their pots plain and were using them not just for special occasions but as ordinary crockery?

\section{Conclusions}

We think the time has come to accept that Lapita pottery does not tell us a single or a simple story. Instead it has lots of stories to tell - depending on time and place. We think it also likely that Lapita was not a monolithic cultural complex; instead, Lapita as a cultural phenomenon was probably a composite (or mosaic) of Oceanic traits (undoubtedly only some thus far identified; only some expressed at all or most Lapita pottery sites). Importantly, each element in this trait mosaic has probably had its own history, its own spatial and temporal distribution (Sapir 1916: 28-9). The histories of some of these traits probably did first come together in the Bismarcks. How they did so is unques- tionably part of the whole story of Pacific prehistory. When we tell this story, we should not forget what Edward Sapir (1916: 4-5, 15, 1819) taught: a 'culture complex' is not 'the whole of a culture'; associated cultural phenomena (the art, tools, songs, rites, legerdemain and prayers of funerary rituals or dance complexes, for example) can be learned, traded, stolen and in other ways shared as a culture complex by people who are in other respects quite different from each other. It may well be that people from one particular place in the Bismarck Archipelago were mainly responsible for expanding the eastward range of some (but probably not all) of the culture traits that we now think of as the Lapita cultural complex. It seems probable, however, that after those traits got to new places in remote Oceania, by whatever means, each again had its own historical trajectory, again depending on time and place. We also think the give-and-take of ideas and things in the voyaging corridor between the regions that are now labelled 'Island Southeast Asia' and 'Melanesia' continued after Lapita came together as such in the Bismarcks (e.g. Bellwood 1992; Bellwood \& Koon 1989; Kirch 1995; Spriggs 1989: 607; 1996b). Finally, we suspect that human subsistence throughout the voyaging corridor during the mid Holocene (say 4500-2000 years ago) was probably based on a spectrum of food resources - wild and domesticated, Asian and Melanesian - and not on a handful of domesticated species of Asian origin. We doubt, in other words, that 'domestication' or 'agriculture' (or 'horticulture') explains what happened in the voyaging corridor $c .3000-4000$ years ago.

In this light, we think the parameters of disagreement among the three Lapita models we have constructed are more rudimental than sometimes believed. These several ways of looking at Lapita history differ not only in where they say Lapita was created as a pottery style or cultural complex. They are also significantly different conceptions of the temporal geography of the past. As solutions to the riddle of Lapita, they rely on different conceptions of process, geographic scale, temporal duration, human agency, motivation and temporal patterning (TABLE 5). By differing so, it might be argued that each of these (pre-)historical reconstructions is a different solution to a different riddle.

It should be apparent that, given these three models, we like the third. Oceania has long been 
thought of as a region of isolated societies related to one another more by descent from the same ancestral tradition than by continuing social, political and economic interaction. The apparent marginality of island societies has led many scholars to think that human biology, language and culture have co-evolved in this part of the world in such an orderly fashion that language can be used to circumscribe populations and reconstruct their ancient migrations and culture history. Cultural evolution in the Pacific has often been seen as a process of human dispersal and subsequent differentiation, or radiation, in isolation from a common source somewhere in Asia or the Americas. During the pioneering phase of anthropological field research in the Pacific after the Second World War, the simplifying assumption that people who live on islands live isolated lives played a useful role (Terrell et al. 1997). But scholars are now working to improve the historical realism of their claims and reconstructions. This shift in orientation promises to unify the study of history and synchronic analysis in the Pacific as 'parts of one universe of discourse, of one order or level of the human social process' (Lesser 1961: 47).

Acknowledgements. Our research has been funded by grants from the National Science Foundation (BNS-8819618; DBS9120301; SBR-9506142), the National Endowment for the Humanities (RO-22203-91), Walgreen Company, The Field Museum and private donors. We thank Peter Bellwood, Paul Gorecki, Terry Hunt, Ian Lilley, Geoff Irwin, Baiva Ivuyo, Alois Kuaso, Jack MacDonald, Robert Mondol, Wilfred Oltomo, Peter Sheppard, Glenn Summerhayes, Pamela Swadling, Michael Therin and Cecelia Wagner for information, research assistance or comments.

\section{References}

ADAMS, W.Y., D.P. VAN GERVEN \& R.S. LEVY. 1978. The retreat from migrationism, Annual Review of Anthropology 7; $483-532$.

AKazAWA, T. \& E.J.E. SzathmÁRY (ed.). 1996. Prehistoric Mongoloid dispersals. Oxford: Oxford University Press.

ALLEN, J. 1972. The first decade in New Guinea archaeology, Antiquity 46: 180-90.

1984. In search of the Lapita homeland: reconstructing the prehistory of the Bismarck Archipelago, Journal of $\mathrm{Pa}$ cific History 19: 186-201.

1991. Introduction, in Allen \& Gosden (ed.): 1-8.

1994. Radiocarbon determinations, luminescence dating and Australian archaeology, Antiquity 68: 339-43.

1996. The pre-Austronesian settlement of island Melanesia: implications for Lapita archaeology, in W.H. Goodenough (ed.), Prehistoric settlement of the Pacific: 11-27. Philadelphia (PA): American Philosophical Society. Transactions $86(5)$.

ALLEN, J., \& G. GOSDEN (ed.). 1991. Report of the Lapita Homeland Project. Canberra: Department of Prehistory, Research School of Pacific Studies, Australian National University. Occasional Papers in Prehistory 20.

1996. Spheres of interaction and integration, in Davidson et al. (ed.): 183-97.

ALLEN, J. \& S. HOLDAWAY. 1995. The contamination of Pleistocene radiocarbon determinations in Australia, Antiquity 69: 101-12.

ALLEN, J. \& J.P. WHTte. 1989. The Lapita homeland: some new data and an interpretation, Journal of the Polynesian Society 98 : $129-46$.

Ambrose, W. 1997. Contradictions in Lapita pottery, a composite clone, Antiquity 70: 525-38 (above, this issue).

ANDERSON, A. 1995. Current approaches in east Polynesian colonization research, Journal of the Polynesian Society 104: 110-32.

1996. Adaptive voyaging and subsistence strategies in the early settlement of east Polynesia, in Akazawa \& Szathmáry (ed.): 359-73.

BAILEY, G. \& J. PARKington. 1988. The archaeology of prehistoric coastlines: an introduction, in G. Bailey \& J. Parkington [ed.], The archaeology of prehistoric coastlines: 1-10. Cambridge: Cambridge University Press.

BAteson, G. 1936. Naven. Cambridge: Cambridge University Press.

BAYLISS-SMITH, T. \& J. GOLSON. 1992, A Colocasian revolution in the New Guinea highlands?: insights from Phase 4 at Kuk, Archaeology in Oceania 27: 1-21.

BELLwoOD, P. 1975. The prehistory of Oceania, Current Anthropology 16: 9-28.

1976. Archaeological research in Minahasa and the Talaud Islands, northeastern Indonesia, Asian Perspectives 19: 240-88.

1978a. Man's conquest of the Pacific: the prehistory of Southeast Asia and Oceania. Auckland: Collins.

1978b. The Polynesians; prehistory of an island people. London: Thames \& Hudson.

1985. Prehistory of the Indo-Malaysian archipelago. Sydney: Academic Press.

1988. A hypothesis for Austronesian origins, Asian Perspectives 26: 107-17.

1989a. Are there antecedents for Lapita in island south east Asia? Paper give at the Circum-Pacific Prehistory Conference, Seattle (WA], August.

$1989 \mathrm{~b}$. The colonization of the Pacific: some current hypotheses, in A.V.S. Hill \& S.W. Serjeantson (ed.), The colonization of the Pacific: a genetic trail: 1-59. Oxford: Oxford University Press.

1991. The Austronesian dispersal and the origin of languages, Scientific American 265(1): 88-93.

1992. New discoveries in southeast Asia relevant for Melanesian (especially Lapita) prehistory, in Galipaud (ed.): 49-66.

1993. Crossing the Wallace Line - with style, in Spriggs et al. (ed.): 152-63.

1995. Comment on 'Predicting similarity in material culture among New Guinea villages from propinquity and language,' by J.M. Roberts et al., Current Anthropology 36: $776-7$.

1996. Early agriculture and the dispersal of the southern Mongoloids, in Akazawa \& Szathmáry (ed.): 287 302

1997a. Ancient seafarers: new evidence of early Southeast Asian sea voyages, Archaeology 50(2): 20-22.

1997b. Prehistory of the Indo-Malaysian archipelago. 2nd edition. Honolulu $(\mathrm{HI})$ : University of Hawai'i Press.

BELLWOOD, P. \& P. KOON. 1989. 'Lapita colonists leave boats unburned!': the question of Lapita links with Island Southeast Asia, Antiquity 63: 613-22. 
BOURKE, R.M. 1990. Subsistence food production systems in Papua New Guinea: old changes and new changes, in Yen \& Mummery (ed.); 148-60.

BRACE, C.L. \& R.J. HINTON 1981. Oceanic tooth-size variation as a reflection of biological and cultural mixing, Current Anthropology 22: 549-69.

BULMER, S. 1996. Revisiting red slip: the Laloki style pottery of southern Papua and its possible relationship to Lapita. Paper (revised, 1997) given at the 3rd Lapita Workshop, Port Vila, Vanuatu, 1-6 August.

BUTI.ER, B.M. 1994. Early prehistoric settlement in the Mariana Islands: new evidence from Saipan, Man and Culture in Oceania 10: 15-38.

CALDWELL, J.R. 1964. Interaction spheres in prehistory, in J.R. Caldwell \& R.L. Hall [ed.], Hopewellian studies; 135-43. Springfield (IL): Illinois State Museum. Scientific Papers 12.

CHAPPELL, J. 1993. Late Pleistocene coasts and human migrations in the Austral region, in Spriggs et al. (ed.): 43-8.

CHEN, L. Z., S. EASTEAL, P.G. BOARD \& R.L. KIRK. 1992. Genetic affinities of Oceanic populations based on RFLP and haplotype analysis of genetic loci on three chromosomes, Human Biology 64: 1-15.

CRAIB, J. 1983. Micronesian prehistory: an archeological overview, Science 219: 922-7

Davidson, J., G. IRWin, F. Leach, A. PAWley \& D. Brown (ed.). 1996. Oceanic culture history: essays in honour of Roger Green. Dunedin: New Zealand Journal of Archaeology. Special Publication.

DickInSON, W. R. 1995. The times are always changing: the Holocene saga, Geological Society of America Bulletin 107: $1-7$

DICKINSON, W.R., D.V. BURLEY \& R. SHUTLER, JR. 1994. Impact of hydro-isostatic Holocene sea-level change on the geologic context of island archaeological sites, northern Ha'apai group, Kingdom of Tonga, Geoarchaeology 9: 85111

EGLOFF, B. 1975. Archaeological investigations in the coastal Madang area and on Eloaue Island of the St Matthias Group. Port Moresby: Papua New Guinea Public Museum and Art Gallery. Records 5.

FLANNERY, T.F. \& J.P. WHITE. 1991. Zoogeography of New Ireland mammals, Resench \& Exploration 7: 96-113.

FrederickseN, C., M. SPRIGGS \& W. AMBrose. 1993. Pamwak rockshelter: a Pleistocene site on Manus Island, Papua New Guinea, in Smith et al. (ed.): 144-52.

Galipaud, J.-C. (ed.). 1992. Poterie Lapita et peuplement. Noumea: ORSTOM.

GELh, A. 1992. The anthropology of time: cultural constructions of temporal maps and images. Oxford: Berg.

GiFford, E.W. \& R. SHITLER, JR. 1956. Archaeological excavations in New Caledonia. Berkeley (CA): University of California Press. Anthropological Records 18(1).

Glover, I. 1986. Archaeology in eastern Timor, 1966-67. Canberra: Department of Prehistory, Research School of Pacific Studies, Australian National University. Terra Australis 11.

Golson, J. 1961. Report on New Zealand, western Polynesia, New Galedonia, and Fiji, Asian Perspectives 5: 166-80.

1972a. Both sides of the Wallace Line: New Guinea, Australia, island Melanesia and Asian prehistory, in N. Barnard (ed.), Early Chinese art and its possible influence in the Pacific Basin 3: 533-95. New York (NY): Intercultural Arts Press.

1972b. The Pacific Islands and their prehistoric inhabitants, in R.G. Ward (ed.), Man in the Pacific Islands: essays on geographical change in the Pacific Islands: 5-33. Oxford: Clarendon Press.

1982. Prehistoric movement and mapping, in R.J. May \& $\mathrm{H}$. Nelson (ed.J, Melanesia: beyond diversity 1: 17-23. Canberra: Research School of Pacific Studies, Australian National University.
GORECKI, P. 1992. A Lapita smoke screen?, in Galipaud (ed.) 27-47.

GORECKI, P., M. MABIN \& J. CAMPBELl. 1991. Archaeology and geomorphology of the Vanimo coast, Papua New Guinea: preliminary results, Archaeology in Oceania 26: 119-22.

GOSDEN, C. 1992. Production systems and the colonization of the western Pacific, Worid Archaeology 24: 55-69.

1995. Arboriculture and agriculture in coastal Papua New Guinea, Antiquity 69: 807-17.

GosDEN, C., et al. 1989. Lapita sites of the Bismarck Archipelago, Antiquity 63: 561-86.

Gosden, C. \& C. PAvlides. 1994. Are islands insular? Landscape vs seascape in the case of the Arawe Islands, Papua New Guinea, Archaeology in Oceania 29: 162-71.

Gosden, C. \& J. WEBB. 1994. The creation of a Papua New Guinean landscape: archaeological and geomorphological evidence, Journal of Field Archaeology 21: 29-51.

GRFEN, R.C. 1968. West Polynesian prehistory, in I. Yawata \& Y.H. Sinoto (ed.), Prehistoric culture in Oceania: a symposium: 99-109. Honolulu (HI): Bishop Museum Press. 1973. Lapita pottery and the origins of Polynesian culture. Australian Natural History (June): 332-7.

1974. Sites with Lapita pottery: importing and voyaging, Mankind 9: 253-9.

1979. Lapita, in Jennings (ed.): 28-60.

1985. Comment: Sprigg's 'The Lapita cultural complex', Journal of Pacific History 20: 220-24.

1987. Obsidian results from Lapita sites of the Reef/Santa Gruz Islands, in W.R. Ambrose \& J.M.J. Mummery (ed.), Archaeometry: further Australasian studies: 239-49. Canberra: Department of Prehistory, Research School of Pacific Studies, Australian National University. Occasional Papers in Prehistory 14

1992. Definitions of the Lapita cultural complex and its non-ceramic component, in Galipaud (ed.): 7-20.

1994. Changes over time: recent advances in dating human colonization of the Pacific Basin area, in D.G. Sutton (ed.), The origins of the first New Zealanders: 19-51. Auckland: Auckland University Press.

1995. Comment on 'Predicting similarity in material culture among New Guinca villages from propinquity and language,' by J.M. Roberts et al., Current Anthropology $36: 778-9$.

1996. Prehistoric transfers of portable items during the Lapita horizon in remote Oceania: a review, Indo-Pacific Prehistory Association Bulletin 15: 119-30.

GROUhE, L.M. 1.967. Models in prehistory: a consideration of the New Zealand evidence, Archaeology \& Physical Anthropology in Oceania 2: 1-27.

HAANTJENS, H.A. et al. 1972. Lands of the Aitape-Ambunti area, Papua New Guinea. Melbourne: CSIRO. Land Research Series 30.

HAGGETI', P. 1966. Locational analysis in human geography. New York (NY): St Martin's Press.

HARDING, T.G. 1967. Voyogers of the Vitiaz Strait: a study of a New Guinea trade system. Seattle (WA): University of Washington Press.

HARRIS, D. 1995. Early agriculture in New Guinea and the Torres Strait divide, Antiquity 69: 848-54.

Hather, J.G. 1992. The archaeobotany of subsistence in the Pacific, World Archaeology 24: 70-81.

HAWKING, S.W. 1988. A brief history of time: from the big bang to black holes. New York (NY): Bantam.

HOPE, G. \& J. GOLSON. 1995. Late Quaternary change in the mountains of New Guinea, Antiquity 69: 818-30.

HunT, T.L. 1987. Patterns of human interaction and evolutionary divergence in the Fiji Islands, Journal of the Polynesian Society 96: 299-334.

1988. Graph theoretic network models for Lapita exchange: a trial application, in Kirch \& Hunt (ed.): 135-55.

IRWIN, G.J. 1983. Chieftainship, kula and trade in Massim prehistory, in J.W. Leach \& E. Leach (ed.), The kula: new 
perspectives on Massim exchonge: 29-72. Cambridge: Cambridge University Press.

1985. The emergence of Mailu as a central place in coastal Papuan prehistory. Canberra: Department of Prehistory, Research School of Pacific Studies, Australian National University. Terra Australis 10.

1989. Against, across and down the wind: a case for the systematic exploration of the remote Pacific Islands, Journal of the Polynesian Society 98: 167-206.

1992. The prehistoric exploration and colonization of the Pacific. Cambridge: Cambridge University Press.

IRWIN, G.J., S. BICKLER \& P. QUIRKE. 1990. Voyaging by canoe and computer: experiments in the settlement of the $\mathrm{Pa}$ cific Ocean, Antiquity 64: 34-50.

IRwiN, G.J. \& S. HoLnAwAY. 1996. Colonization, trade and exchange: from Papua to Lapita, in Davidson of al. (ed.) 225-35

JENNINGS, J.D. (ed.). 1979. The prehistory of Polynesia: $352-$ 77. Cambridge (MA): Harvard University Press.

KENNEDY, J. 1982. Archaeology in the Admiralties: some excursions, Bulletin of the Indo-Pacific Prehistory Association 3: $22-35$.

KIRCH, P.V. 1984. The evolution of the Polynesian chiefdoms Cambridge: Cambridge University Press.

1987. Lapita and Oceanic cultural origins: excavations in the Mussau Islands, Bismarck Archipelago, 1985, Journal of Field Archaeology 14: 163-80.

1988a. Long-distance exchange and island colonization: the Lapita case, Norwegian Archaeological Review 21: $103-17$

1988b. Problems and issues in Lapita archaeology, in Kirch \& Hunt (ed.): 157-65.

1988c. The Talepakemalai Lapita site and Oceanic prehisfory, National Geographic Reseorch 4: 328-42.

1990. Specialization and exchange in the Lapita complex of Oceania (1600-500 BC), Asian Perspectives 29: 11733.

1991. Prehistoric exchange in western Melanesia, Annual Review of Anthropology 20: 141-65.

1995. The Lapita culture of western Melanesia in the context of Austronesian origins and dispersal, in $\mathrm{P}$. Li et al. (ed.) Austronesian studies relating to Taiwan: 255-94. Taipei: Academia Sinica. Symposium Series of the Institute of History and Philology 3.

1997. The Lapita people: ancestors of the Oceanic world. Oxford: Blackwell.

KIRCH, P.V. et al. 1991. Mussau Islands prehistory: results of the 1985-86 excavations, in Allen \& Gosden (ed.): 14463 .

KIRCH, P.V. \& T.L. Hunv (ed.). 1988. Archaeology of the Lapita cultural complex: a critical review. Seatlle (WA): Burke Museum, Research Report 5.

KIRCH, P.V. \& M.I. WEISLER. 1994. Archaeology in the Pacific Islands: an appraisal of recent research, Journat of Archaeological Research 2: 285-328.

LESSER, A. 1961. Social fields and the evolution of society, American Anthropologist 17: 40-48.

LILlEY, I. 1986. Prehistoric exchange in the Vitiaz Strait, Papua New Guinea. Unpublished Ph.D thesis, Australian National University, Canberra,

LOY, T.H., M. SPRTGGS \& S. WICKLER, 1992. Direct evidence for human use of plants 28,000 years ago: starch residues on stone artefacts from the northern Solomon Islands. $A n$ tiquity 66: 898-912.

NEI, M. \& N. TAKLZAKI. 1996. The root of the phylogenetic tree of human populations, Molecular Biology and Evolution $13: 170-77$

PAvlides, C. \& C. Gosden, 1994. 35,000-year-old sites in the rainforests of West New Britain, Papua New Guinea, Antiquity 68: 604-10.

POLLSEN, J. 1987. Early Tongan prehistory: the Lapita period on Tongatapu and its relationships. Canberra: Depart- ment of Prehistory, Research School of Pacific Studies, Australian National University. Terra Australis 12.

ROSCOE, P. 1989. The pig and the long yam: the expansion of a Sepik cultural complex, Ethnology 28: 219-31.

Ross, M. 1988. Proto Oceanic and the Austronesian languages of western Melonesia. Canberra: Research School of Pacific Studies, Australian National University. Pacific Linguistics C-98.

1989. Early Oceanic linguistic prehistory, Journal of $P Q$ cific History 24: 135-49.

1991. How conservative are sedentary languages?: evidence from western Melanesia, in R. Blust (ed.), Currents in Pacific linguistics: papers on Austronesian languages and ethnolinguistics in honour of George W. Grace: 433-51. Canberra: Research School of Pacific Studies, Australian National University. Pacific Linguistics C-117.

ROUSE, I. 1986. Migrations in prehistory: inferring population movement from cultural remains. New Haven (CT): Yale University Press.

SAPIR, E. 1916. Time perspective in aboriginal American culture, a study in method. Ottawa: Government Printing Bureau. Memoir 90, Geological Survey, Department of Mines. Anthropological Series 13.

SHEPPARJ, P. 1996. Hard rock: archaeological implications of chert sourcing in near and remote Oceania, in Davidson et al. (ed.): 99-115.

Sherrat, A. 1993. The relativity of theory, in N. Yoffee \& A. Sherratt (ed.), Archaeological theory: who sets the agenda? 119-30. Cambridge: Cambridge University Press.

SHUtLER, R., JR \& J.C. MARCK. 1975. On the dispersal of the Austronesian horticulturalists, Archaeology \& Physical Anthropology in Oceania 10: 81-113

SIORAT, J.P. 1990. A technological analysis of Lapita pottery decoration, in Spriggs (ed.): 59-82.

SMITH, A. 1995. The need for Lapita: explaining change in the Late Holocene Pacific archaeological record, World Archaeology 26: 366-79

Smith, M.A., M. Spriggs \& B. Fankhauser (ed.). 1993. Sahul in review: Pleistocene archaeology in Australia, New Guinea and Island Melanesia. Canberra: Research School of Pacific Studies, Australian National University. Occasional Papers in Prehistory 24.

SOLHEIM, W.G. 1964. Further relationships of the Sa-HuynhKalanay pottery tradition, Asian Perspectives 8: 196-211.

SPRIGGS, M. 1984. The Lapita cultural complex: origins, distribution, contemporaries and successors, Journal of Pacific History 29: 202-23.

1989. The dating of the Island Southeast Asian Neolithic: an attempt at chronometric hygiene and linguistic correlation, Antiquity 63: 587-613.

(ed.). 1990. Lapita design, form, and composition: proceedings of the Lapita design workshop, Canberra, December 1988. Canberra: Department of Prehistory, Research School of Pacific Studies, Australian National University. Occasional Papers in Prehistory 19.

1993a. Island Melanesia: the last 10,000 years, in Spriggs et al. (ed.): 187-205.

1993b. Pleistocene agriculture in the Pacific: why not?, in Smith et al. (ed.): 137-43.

1996a. Chronology and colonization in island southeast Asia and the Pacific: new data and an evaluation, in Davidson et al. (ed.): 33-50.

1996b. What is Southeast Asian about Lapita?, in Akazawa \& Szathmáry (ed.): 324-48.

SPRIGGS, M. \& C. CHIPPINDALE. 1989. Introduction to Special section, 'Early settlement of Isiand Southeast Asia and the western Pacific', Antiquity 63: 547.

SPRiggs, M., D.E. YeN, W. AMHROSE, R. JONES, A. THORNE \& A ANDREWs (ed.). 1993. A community of culture: the people and prehistory of the Pacific. Canberra: Research School of Pacific Studies, Australian National University. Occasional Papers in Prehistory 21. 
SUGGS, R.G. 1960. The island civilizalions of Polynesia. New York (NY): New American Library.

SUMMERHAYES, G. 1996. Interaction in Pacific prehistory: an approach based on the production, distribution, and use of pottery. Unpublished Ph.D dissertation, LaTrobe University.

Swam ING, P. 1990. Sepik prehistory, in N. Lutkehaus et al. (ed.), Sepik heritage: tradition and change in Papua New Guinea: 71-86. Durham (NC): Carolina Academic Pross.

1996. Plumes from paradise: trade cycles in outer Southeast Asia and their impact on New Guinea and nearby islands tintil 1920. Boroko: Papua New Guinea National Museum and Robert Brown \& Associates.

SWAdLINC, P., N. AKAHO \& B. IVUYO. 1991. Settements associated with the inland Sepik-Ramu Sea, Indo-Pacific Prehistory Association Bulletin 11: 92-112.

SwaDlivg, P. et al. 1988. The Sepik-Ramu: an introduction. Boroko (NCT): National Museum and Art Gallery.

1989. A Late Quaternary inland sea and early pottery in Papua New Guinea, Archaeology in Oceania 24: $106-$ 9.

SWADLING, P. \& G. HOPE. 1992. Environmental change in New Guinea since human settlement, in J.R. Dodson (ed.), The naive lands: prehistory and environmental change in Australia and the sauthwest Pacific: 13-42. Melbourne: Longman Cheshire.

TERRELL, J.E. 1974. Comparative study of human and lower animal biogeography in the Solomon Islands. Chicago (IL): Department of Anthropology, Field Museum of Natural History. Solomon Island Studies in Human Biogeography 3.

1986. Prehistory in the Pacific Islonds. Cambridge: Cambridge University Press.

1988. History as a family tree, history as an entangled bank: constructing images and interpretations of prehistory in the south Pacific, Antiquity 62: 642-57.

1989. Commentary: what Lapita is and what Lapita isn't, Antiquity 63: 623-6.

1990. Storytelling and prehistory, Archaeological Method and Theory 2: 1-29.

1996. Lapita as history and culture hero, in Davidson et al. (ed.): 51-66.

TERrELL, J.E., T.L. HuNT \& C. GOSDEN. 1997. The dimensions of social life in the Pacifis: human diversity and the myth of the primitive isolate, Current Anthropology 38: 155-95.

TERRELL, J.E. \& G.J. IRWIN. 1972. History and tradition in the northern Solomons: an analytical study of the Torau migration to southern Bougainville in the $1860 \mathrm{~s}$, Journal of the Polynesian Society 81: 317-49.

TERRELL, J.E. \& R.L. WELSCH. 1990. Trade networks, areal integration, and diversity along the north coast of New Guinea, Asian Perspectives 29: 156-65.

TORRENCE, R. 1986. Production and exchange of stone tools. Cambridge: Cambridge University Press.
1994. Processes and events: differential rates of change in the Talasea region of West New Britain. Papua Now Guinea. Paper given at the Indo-Pacific Prehistory Association 15 th Congress, Jamuary.

TORRence, R. \& G.R. Summerhayes. 1997. Socialitv and the short distance trader: intra-regional obsidian exchange in the Willaumetz region, Papua New Guinea, Archaeology in Oceania 32: 74-84.

TORRENCE, R. \& K.L. VICTOR. 1995. The relativity of density, Archaeology in Oceania 30: 121-31.

TYKOT, R.H. \& S. CHIA. 1997. The longest Stone Age trade ronte in the world: scuth west Pacific obsidian reached Borneo (Malaysia) in the 5th Millennium BC. Paper given at the annual meetings, Society for American Archaeology, Nashville (TN), April 5.

WELSCH, R.L. 1996. Language, culture, and data on the north coast of New Guinea, Quantitative Anthropology 6: 209-34.

In press a. An American anthropologist in Melanesia before the Great War: the field diaries of Albert B. Lewis during the J.N. Field South Pacific Expedition, 1909-1913. Honolulu [III): University of Hawaii Press.

In press b. Collaborative regional anthropology in New Guinea: from the New Guineu micro-evolution project to the A.B. Lewis project and bevond, Pacific Studies.

N.d. Historical ethnology: the context and meaning of the A.B. Lewis collection. MS

WELSCH, R.L. \& J.E. TERREI.I. 1991. Continuity and change in economic relations along the Aitape coast of Papua New Guinea, 1909-1990, Pacific Studies 14: 113-28.

1994. Reply to Moore and Romney, American Anthropologist 96: 392-6.

In press. Material culture, social fields, and sociai boundaries on the Sepik coast of New Guinea, in M. Stark (ed.), Technical choices and social boundaries in material culture patterning. Washington (DC): Smithsonian Institution Press.

WELSCH, R.L.. J.E. TERRELL \& J. NADOLSKI. 1992. Language and culture on the north coast of New Guinea, American Anthropologist 94: 568-600.

WHITE, J.P. 1979. Melanesia, in Jennings (ed.): 352-77.

WHITE, J.P, \& J. ALLEN. 1980. Melanesian prehistory: some recent advances, Science 207: 728-34.

WHITE, J.P., I.E. DOWNIE \& W.R. AMBROSE. 1978. Mid-Recent human occupation and resource exploitation in the Bismarck Archipelago, Science 199: 877-9.

Williams, G. C. 1966. Adaptation and natural selection. Princeton (NJ): Princeton University Press.

YEN, D.E. 1990. Environment, agriculture and the colonization of the Pacific, in Yen \& Mummery (ed.): 258-77.

1995. The development of Sahul agriculture with Australia as bystander, Antiquity 69: 831-47.

YeN, D.E. \& J.M.J. MumMerY (ed.). 1990. Pacific production systems: approaches to economic prehistory. Canberra: Research School of Pacific Studies, Australian National University. Occasional Papers in Prehistory 18. 